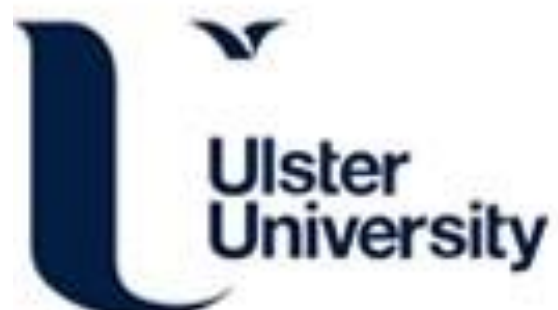

\section{Bedform evolution and dynamics of a geostrophic current-swept shelf, northern KwaZulu-Natal, South Africa}

Green, A. N., Flemming, B., Cooper, A., \& Wanda, T. F. (2021). Bedform evolution and dynamics of a geostrophic current-swept shelf, northern KwaZulu-Natal, South Africa. Geo-Marine Letters, 42(1), 1. [5]. https://doi.org/10.1007/s00367-021-00722-7

Link to publication record in Ulster University Research Portal

\section{Published in:}

Geo-Marine Letters

Publication Status:

Published (in print/issue): 07/12/2021

DOI:

10.1007/s00367-021-00722-7

\section{Document Version}

Publisher's PDF, also known as Version of record

\section{General rights}

Copyright for the publications made accessible via Ulster University's Research Portal is retained by the author(s) and / or other copyright owners and it is a condition of accessing these publications that users recognise and abide by the legal requirements associated with these rights.

\section{Take down policy}

The Research Portal is Ulster University's institutional repository that provides access to Ulster's research outputs. Every effort has been made to ensure that content in the Research Portal does not infringe any person's rights, or applicable UK laws. If you discover content in the Research Portal that you believe breaches copyright or violates any law, please contact pure-support@ulster.ac.uk. 


\title{
Bedform evolution and dynamics of a geostrophic current-swept shelf, northern KwaZulu-Natal, South Africa
}

\author{
A. N. Green ${ }^{1,2} \cdot$ B. W. Flemming ${ }^{3}$ J. A. G. Cooper ${ }^{1,2} \cdot$ T. F. Wanda $^{1}$
}

Received: 8 February 2021 / Accepted: 25 October 2021

(c) The Author(s) 2021

\begin{abstract}
When compared to tide-dominated shelves, shelves swept by geostrophic flows are relatively understudied, yet geostrophic currents have the potential to construct substantial current-generated shelf bedforms. This paper examines the evolution of a series of bedforms encountered along the narrow Agulhas Current-swept northern KwaZulu-Natal shelf. Their evolution is placed in the context of progressive current impingement and variation in flows associated with the postglacial transgression and culminating in the present-day highstand.

Ultra-high resolution seismic reflection, multibeam, side-scan sonar and single beam data sets reveal several bedform scales and morphologies; wave ripples and shoreface-connected ridges are associated only with the inner shelf, and 2D and 3D very large dunes are more cosmopolitan and span the entire shelf sector. The inner shelf is marked by rock outcrop (aeolianite), surrounded by sandy sediment, grading seaward into sediment starved bedforms associated with bioclastic gravels. Where sufficient sediment exists in local depocenters, very large dunes form discontinuous fields along the outer shelf.

The seismic stratigraphy of the outer shelf reflects the effects of postglacial flooding by rising sea levels and increasing current impingement by the Agulhas Current. The Holocene wave ravinement surface is overlain by flat-lying strata (early dune development and dune amalgamation with first current exposure), in turn covered by hummocky, sub-horizontal aggrading beds (amalgamation), overlain by inclined cross-bedded packages (lee faces of the bedforms formed during migration and full current interaction).

Morphometric analyses show that for both the inner and outer shelf, no relationships exist between water depth, wavelength and spacing. Height to spacing $(\mathrm{H} / \mathrm{L})$ relationships are weak but nevertheless show a broadly positive trend. Bedform heights are lower on the inner shelf compared to the outer shelf, but bedform spacing is greater on the inner shelf, with a $40 \%$ overlap in $\mathrm{H} / \mathrm{L}$ indices observed between the two areas. The departures in overlap can be linked to the competing offshore Agulhas Current and the inshore wave-dominated processes. Bedforms of the inner shelf plot below the global H/L mean and can be related to the more infrequent incursions of the Agulhas Current core. At the time of survey, the Agulhas Current was likely situated well offshore, resulting in reduced current activity in the survey area resulting in rounding of the dune crests, degradation of the dune crests and trough infilling. On the outer shelf, the $\mathrm{H} / \mathrm{L}$ values plot above the mean global trend, suggesting vertical accretion due to the faster currents. Crest rounding and downlapping of the upstream lee faces onto the downstream stoss faces indicate dune degradation, which is related to a seaward location of the Agulhas Current at the time of survey.
\end{abstract}

\section{Introduction}

\section{A. N. Green}

1 School of Agricultural, Earth and Environmental Sciences, University of KwaZulu-Natal, Durban, South Africa

2 School of Environmental Sciences, University of Ulster, Coleraine BT52 1SA, UK

3 Abteilung Meeresforschung, Senckenberg Gesellschaft Für Naturforschung, Suedstrand 40, 26318 Wilhelmshaven, Germany
Geostrophic currents that impinge the shelf, occasional storm surges and/or tidal currents have the potential to contribute to construction of shelf bedforms. Tide-dominated shelves have higher sediment-retaining capabilities because shelf sediments are reworked back and forth, often resulting in large bedforms with little net movement (e.g. Jones et al. 2009). In contrast, large bedforms can develop on geostrophic current-dominated shelves in response to variations in current velocity, but their net movement is in the same 
Fig. 1 Locality map of the study area juxtaposed with the general bathymetry of the SW Indian Ocean (from Dorschel et al. 2018). Lower image, data extents and localities of the ensuing figures

direction as the current. During transgression, the relative position and strength of geostrophic currents with respect to the shelf are likely to vary as water depth and shelf width increase progressively. Current interaction with the seabed will, similarly, evolve in terms of the potential to generate bedforms and in the nature of those bedforms. Concomitant changes in shelf sediment distribution occur through wave ravinement (in shallow water) and current transport (offshore).

In contrast to tide-dominated shelves, much less attention has been given to shelves swept by geostrophic flows, especially western boundary currents. The northern KwaZuluNatal shelf, off the east coast of South Africa (Fig. 1), is one of the few such shelves. Others include the SE Atlantic margin of North America (the Gulf Stream) (Betzer et al. 1974; Swift and Freeland 1978; Swift et al. 1979; Huthnance 1992) and the western margin of Japan (the Kuroshio Current and its branches) (Ikehara 1988, 1989; Ikehara and Kinoshita 1994; Park et al. 2003; Kubo et al. 2004).

Sedimentary bedforms, such as very large dunes, are apparent on the northern KwaZulu-Natal Shelf, and are presumed to be formed by bottom impinging geostrophic currents. It is, therefore, the aim of this paper is to relate the type, orientation, evolution and stratigraphic signatures of current-generated bedforms on the northern KwaZuluNatal shelf (SE African continental margin) to progressive western boundary current impingement and variable flow conditions during the postglacial sea-level rise. To examine this relationship, we utilise new high-resolution multibeam coverage of large bedforms and combined sidescan-sonar/ single beam bathymetry, as well as shallow seismic data from a $230-\mathrm{km}$-long shelf sector.

\section{Regional setting}

\section{Physical setting}

The continental shelf of the northern KwaZulu-Natal region is narrow $(<5 \mathrm{~km})$, especially so from offshore Kosi Mouth to Cape St. Lucia (Fig. 1). The shelf is therefore recognised as one of the world's narrowest (Martin and Flemming 1988), being significantly narrower than Shepard's (1963) global average of $50 \mathrm{~km}$. The shelf break generally occurs at a water depth of $\sim 100 \mathrm{~m}$ (Green 2009a), although, in some areas where large submarine canyons impinge on the shelf, it is as shallow as 65 m (e.g. offshore Sodwana Bay) (Ramsay 1991; Ramsay et al. 1996) (Fig. 1).
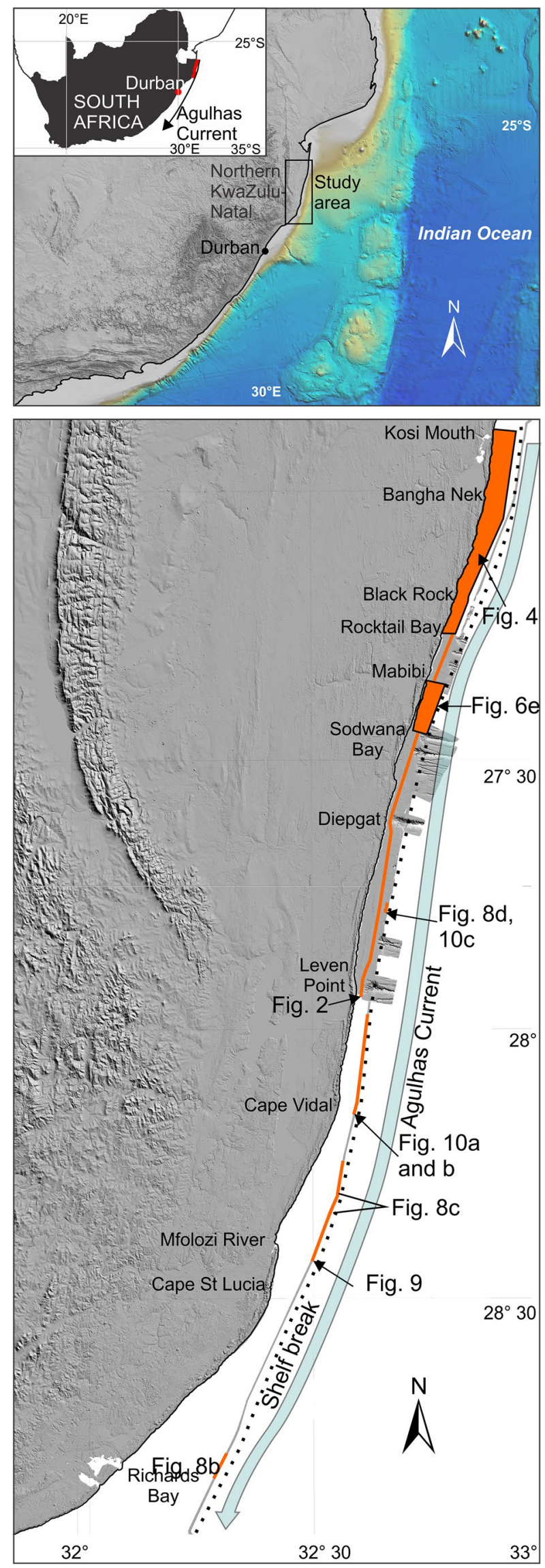
The SE African continental shelf is characterised by several Holocene-age depocentres (Martin and Flemming 1986; Birch 1996) (Fig. 2). These depocenters occur offshore of coastal offsets (Fig. 2d), are associated with fluvial entry points to the shelf such as the Mfolozi River, the largest to enter the study area (Fig. 2d) and occur in tandem with incised valley fills (Fig. 2b, c, e) (Green 2009a). Large-scale subaqueous dunes form in these unconsolidated sediments during interactions with the dominant southwesterly-driven Agulhas Current (Flemming 1978, 1981; Martin and Flemming 19888; Flemming and Hay 1988; Ramsay 1994; Ramsay et al. 1996). During late Pleistocene times, the last glacial maximum (LGM) sea level of - $130 \mathrm{~m}$ (Green and Uken 2005) would have left the shallow shelf break of the northern KwaZulu-Natal continental shelf subaerially exposed to accumulate a substantial volume of unconsolidated coastal plain sediments.

\section{Regional geology}

The northern KwaZulu-Natal continental shelf and coastal plain are underlain by Mesozoic to Pleistocene/Holocene aged rocks (Dingle et al. 1983), which document the rifting and drifting phases of the passive margin development of SE Africa (McMillan 2003). Overlying the basement volcanics (Lebombo Group volcanics according to Watkeys et al. 1993) is a succession of Cretaceous sedimentary rocks (Shone 2006) of the Zululand Group's St. Lucia Formation (Dingle et al. 1983). Overlying the Cretaceous age rocks is a Pliocene-aged shelf-edge wedge (Green et al. 2008). On the inner shelf, these Cretaceous rocks are truncated by several palaeo-river systems, the youngest of which relate to the LGM lowstand (Green 2009a, 2011). Overlying the subaerial unconformity offshore are Pleistocene and Holoceneaged beachrocks and aeolianites (Ramsay 1994; Green et al. 2018).

Ramsay (1991, 1994) and Ramsay et al. (1996) considered the most prominent consolidated lithologies on the northern KwaZulu-Natal shelf to comprise linear coast-parallel beachrock and aeolianites of late Pleistocene age. These submerged beachrock/aeolianite complexes are partly covered by unconsolidated Holocene sediment from 0 to $30 \mathrm{~m}$ thick (Flemming 1978; Ramsay 1994; Ramsay et al. 1996).

\section{Hydrodynamics and sedimentology}

Many authors have examined the physical oceanography of the Agulhas Current off the northern KwaZulu-Natal coast (e.g. Schumann 1988; Lutjeharms 2006). The current travels at speeds of up to $\sim 1.5 \mathrm{~m} \mathrm{~s}^{-1}$ (Flemming 1978, 1980), with flow thicknesses of up to $2000 \mathrm{~m}$ in the study area (Lutjeharms et al., 2010). The core of the Agulhas current is generally located over deep water, $\sim 50$ nautical miles offshore in about $1300 \mathrm{~m}$ of water (Bryden et al. 2005; Lutjeharms et al. 2010) but has been shown to meander, occasionally strongly impinging the shelf water masses (Lutjeharms 2006). As a consequence, the current components over the middle and outer shelf follow suit by shifting laterally further shoreward or further offshore in response (Flemming 1978; Flemming and Bartholomä 2012). The region is microtidal, with a wave-dominated inner shelf mantled by mobile, medium to coarse sands and gravels, and a geostrophic current-dominated middle to outer shelf comprising relict coarse sands and gravels surrounded by local depocentres (Flemming 1980; Flemming and Kudrass 2018).

The average significant wave height for the KwaZuluNatal coast is $1.65 \mathrm{~m}$ (Corbello and Stretch, 2012), with frequent northward-travelling storm events that exceed $3 \mathrm{~m}$ (Salzmann and Green 2012). The average peak wave period is $10 \mathrm{~s}$ (Corbello and Stretch 2012) with a deep-water wavelength of 156 m (Komar 1998). Komar's (1998) conservative definition of wave base considers wave base to be the deep-water wavelength divided by 4 , thus placing the average storm weather wave base at a depth of $39 \mathrm{~m}$. The wave period for the largest storm in recorded history was $16.6 \mathrm{~s}$ (Salzmann and Green 2012), thus proving a threshold for storm-driven sediment movements at a depth of $\sim 107 \mathrm{~m}$.

Flemming (1981) and Ramsay et al. (1996) showed that the net sediment transport direction along the SE African shelf is to the south, with short-period reversals that form occasional northward migrating bedforms. Contradicting sediment directions generally relate to bedload partings/ convergences and are controlled by local flow reversals along the inner boundary of the Agulhas Current, often in the lee of coastal offsets (Flemming 1981; Ramsay 1994; Ramsay et al. 1996; Green 2009b). Flemming (1981) noted that north-eastward counter currents are more common in the north (with increasing number of coastal bays and offsets). Northward-directed counter currents may also be driven by the large storms discussed above; however, these are months-long, persistent flows as opposed to the episodic occurrences expected in association with storms (see panel 1 in Fig. 9 of Flemming and Kudrass 2018).

Ramsay et al. (1996) considered that the interception of south-moving shelf sediments by a series of submarine canyon systems leads to loss of sediment from the outer shelf, leaving it sediment starved. More recently Green (2009b) showed localised flow reversal cells at the heads of these canyons, which generate localised bedform fields that are not entrained into the canyon heads.

\section{Dimensional adjustments of subaqueous dunes}

As it is the hypothesis of this study that sediment dunes on the northern KwaZulu-Natal Shelf are a consequence of geostrophic current-sea bottom interaction, it is important 
Fig. 2 Unconsolidated sediment isopach maps for the study area, maps are based on available data coverage. a. Mabibi. A thin sediment cover occurs, associated with a mid-shelf bedform field. b. Diepgat canyon to Sodwana Bay (up to White sands canyon). Thickest sediment cover is associated here with incised valleys on the shelf. c. Leven Point. This area is marked by relatively thin cover, with thickest sediment occurring near the head of Leven canyon in association with an incised valley. d. Cape Vidal to Cape St Lucia. This area is marked by thick accumulations of sediment associated with fluvial entry points and coastal offsets (isopach derived from Martin and Flemming, 1985). e. Along strike seismic profile ( adapted from Green 2009a) showing the unconsolidated sediment layer in addition to local depocenters formed by incised valley fills (IVFs). SB1 refers to the bedrock-unconsolidated sediment contact
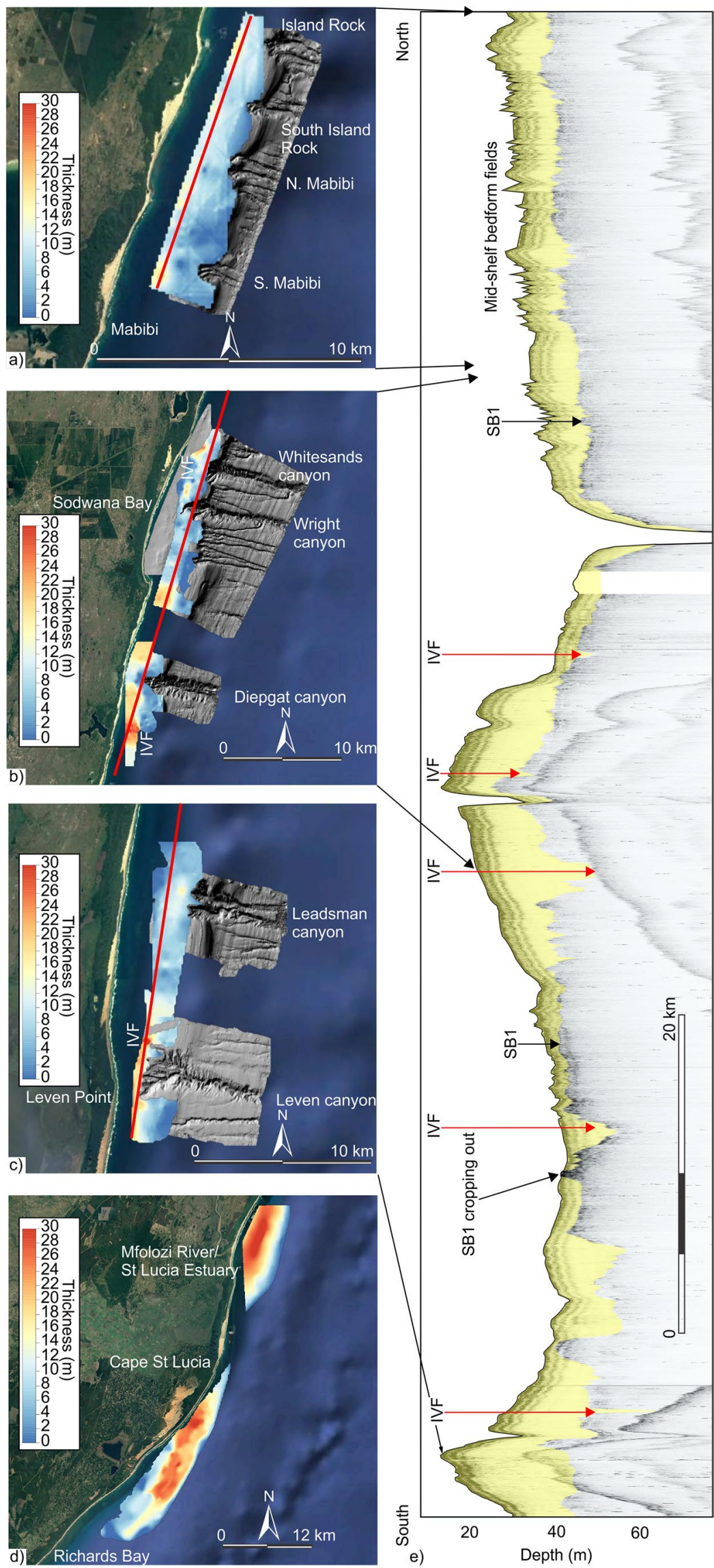
to understand the nature of the growth and decay of such marine bedforms. Dune amalgamation and splitting are implicit in the three-dimensional model (water depth vs current velocity vs grain size) of Rubin and McCulloch (1980). Flemming (2000) subsequently proposed a conceptual model for how dunes adjust to changes in flow regime based on the observation of a $20 \%$ velocity change from spring to neap tide in a Wadden Sea tidal channel. In principle, dunes grow in height due to the amalgamation of smaller dunes into larger ones as flow velocity increases. If coarser grain sizes occur, this requires overall stronger velocities. This process is inherently reversible, i.e. dunes may split due to reductions in velocity. Progressive dune splitting is also evident where flow velocities decrease laterally to the main flow axis (Flemming 1980, 2000). A good recent overview of such processes in rivers is presented by Reesink et al. (2018).

As dunes amalgamate, larger dunes are produced by smaller dunes where their volumes are combined (Fig. 3a).
Fig. 3 Schematic diagram highlighting the processes of dune modification and amalgamation (heights are exaggerated but proportionally correctly scaled). a. Sediment budget considerations: there is an $\sim 40 \%$ deficit created by amalgamation of two small dunes into one larger dune having twice the spacing. b. Base level lowering through scouring in the trough to compensate for the deficit. c. Progression to sediment starved dunes if lowering of the base level is prevented by hardgrounds. d. Dune crest degradation due to current cessation, causing reworking of the dune crests by smaller bedforms and sediment deposition in the dune troughs. Note the rounded crests and onlapping of the downstream stoss face by upstream lee faces
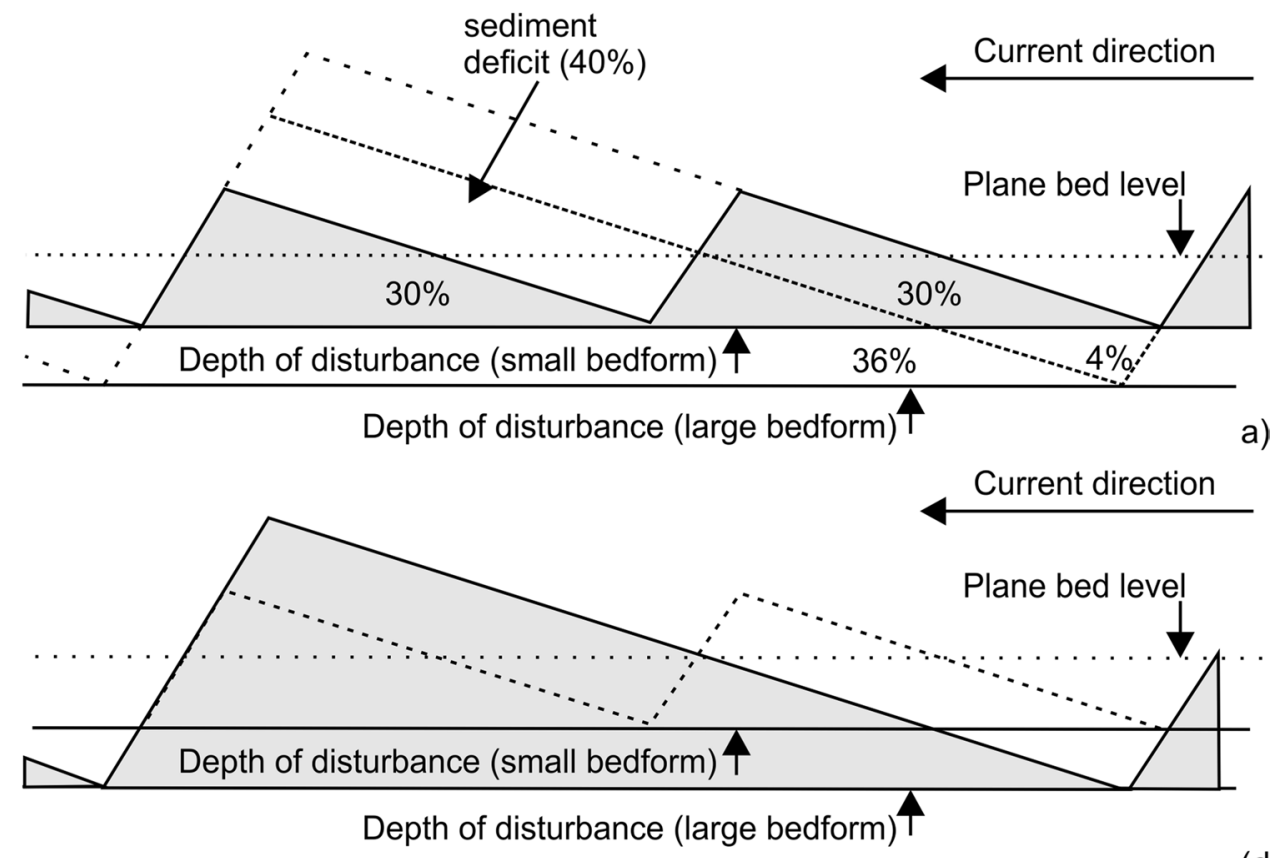

Current direction

(d

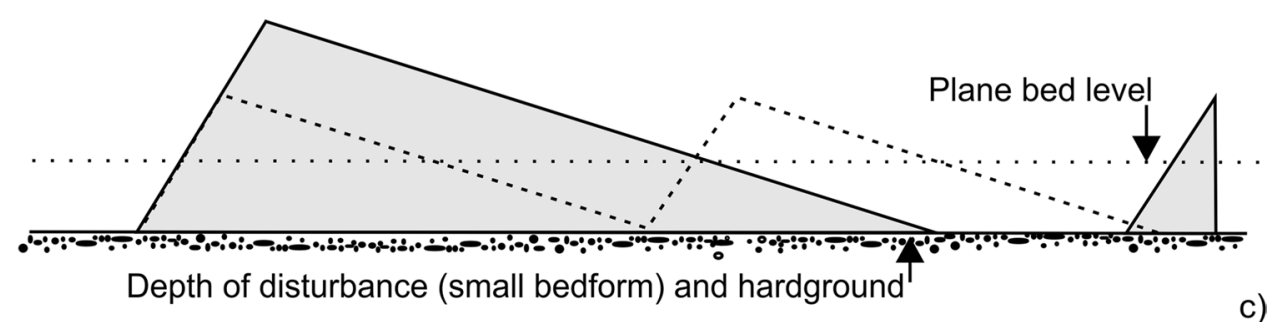

Current direction

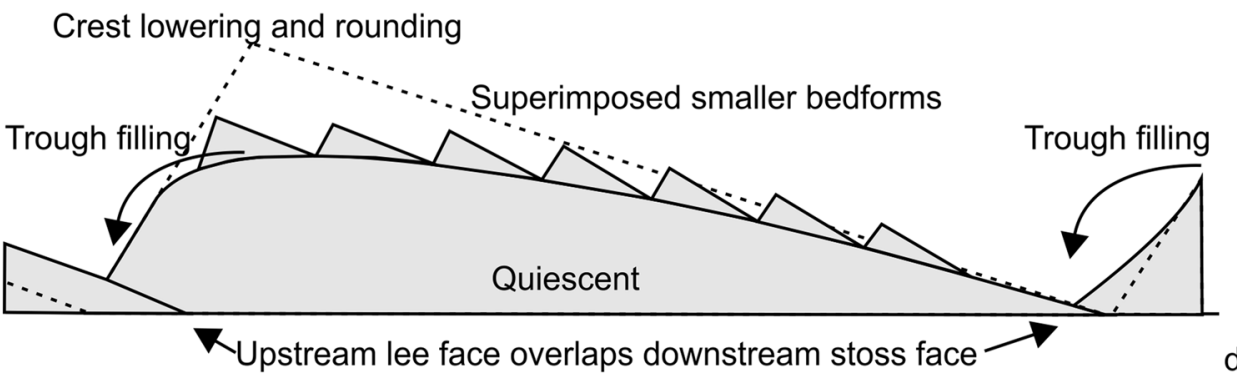


To produce a closed dune field (i.e. there are no sedimentfree gaps between each dune form) by doubling the spacing of the dunes, a sediment deficit of $40 \%$ arises to build the new and larger dune. This is often sourced by excavating the trough deeper to the new depth of disturbance of the larger dune (Fig. 3b).

During migration and amalgamation, closed dune successions may excavate their bases to a non-erodible surface (Fig. 3c). In this case, large dunes can no longer meet the $40 \%$ deficit encountered during amalgamation and sediment starvation is induced. This starvation further lowers the crests of the dunes and produces serrated edges at the upstream stoss of successive dunes (Flemming 1981).

A final change to dune height may occur where the current activity decreases dramatically and independent of sediment starvation (Fig. 3d) (Flemming 2013). In this case, flow velocity is lower than the critical level for the splitting of large dunes, and weaker flows thus degrade the dune form by slowly moving sediment, possibly through the migration of ripples or smaller dunes, from the crests to the troughs. The migration of smaller dunes reduces crest elevation and raises the trough accordingly, causing a rounding of the dune crests.

\section{Material and methods}

Approximately $350 \mathrm{~km}$ of multibeam data was collected over the outer to middle regions of the northern KwaZulu-Natal shelf on the $16^{\text {th }}$ and $17^{\text {th }}$ of March, 2016, using a Kongsberg EM710 multibeam echosounder aboard the RV Meteor (cruise M123). Positioning was achieved using a differential GPS with an accuracy of $\sim 1 \mathrm{~m}$. Sounding position and depths were corrected for refraction and tidal heights using Beamworx where sound velocity profiles, acquired using Expendable Bathythermographs (XBT), were incorporated, together with tidal variations derived from the South African Navy tide charts. Vessel motion was modelled using a Kongsberg Seapath 300 system. All soundings were reduced to mean sea level and spurious data edited out to produce a final bathymetric footprint of $2 \times 2 \mathrm{~m}$.

These data were further supplemented by coincident ultra-high resolution PARASOUND sub-bottom data with an internal resolution of $\sim 10 \mathrm{~cm}$. The data were processed aboard ship for the $3.5-\mathrm{kHz}$ low-frequency channel, where they were match-filtered and exported as processed SEGY data. These were imported into Hypack 2017, where stratigraphic analyses of the internal architectures were performed.

Portions of the inner shelf of northern KwaZulu-Natal were imaged using a Klein 3000 digital side scan sonar at $100 \mathrm{kHz}$ and $500 \mathrm{kHz}$ with a 75-m scan range to enable viewing of the seafloor sedimentary characteristics. Only the $100-\mathrm{kHz}$ frequency port and starboard channels were used in this study. Processing details are available in Ramsay et al. (2006). Single-beam bathymetry was also collected simultaneously to define the seafloor morphology (Ramsay et al. 2006). A Navisound 210 single frequency, digital survey echosounder was used to collect the bathymetric data, operating at a frequency of $200 \mathrm{kHz}$. The echosounder was interfaced to a TSS HS50 heave sensor to correct the water depths for vessel swell movement. Data were collected in May 2003.

The side scan mosaics and bathymetry data were imported into ArcGIS, where the data were used to create side scan sonar-draped sun-shaded digital elevation models of the shelf. From here, quantitative measurements of bedform parameters (depth, wavelength and height) were obtained from multiple cross sections. All subaqueous bedform descriptions are based on the classification scheme of Ashley et al. (1990), where crest to crest spacings of $1 \mathrm{~m}, 10 \mathrm{~m}, 100 \mathrm{~m}$ and $1 \mathrm{~km}$ relate to dunes, large dunes, very large dunes and ridges respectively. Dunes are further described on the basis of shape, where 2D dunes are straight crested, and 3D dunes are curved to sinuous crested (Ashley et al. 1990).

\section{Results}

\section{Bathymetry and bedforms of the inner to outer shelf}

The inner shelf, up to 30-m water depth, is marked by bedform trains comprising large to very large dunes, their crests oriented coast-perpendicular (Figs. 4 and 5). The deepest of these bedforms occur at $~ 55-\mathrm{m}$ depth, between Rocktail Bay and Bangha Nek. These bedforms impinge the upper shoreface, where they superimpose a series of sigmoidshaped shoreface connected ridges at depths of 25-35 m (Fig. 4). The mid-shelf of the whole study area is marked by a flat, low gradient surface with isolated rugged patches of seafloor at depths of 45-60 m (e.g. offshore Kosi Mouth, Fig. 4a). The rugged patches of seafloor form elongate cusps of higher relief and higher backscatter (e.g. between Kosi Mouth and Rocktail Bay, Fig. 4). The mid shelf to seaward is characterised by even toned, high backscatter (Figs. 4b and 5).

The shelf of Sodwana Bay to Leven Point is marked by beachrock and aeolianite outcrop on the inner shelf (Fig. 6a). The shelf transitions to a flatter mid-shelf before merging with a series of bedforms on the outer shelf from 70 to 100-m depth (Fig. 6b-d).

The bedforms of the study area have wavelengths that span a continuum from the level of the resolution of the geophysical tools (metres) through to kilometres ( 10-3900 m) (see Morphometrics). The largest bedforms 


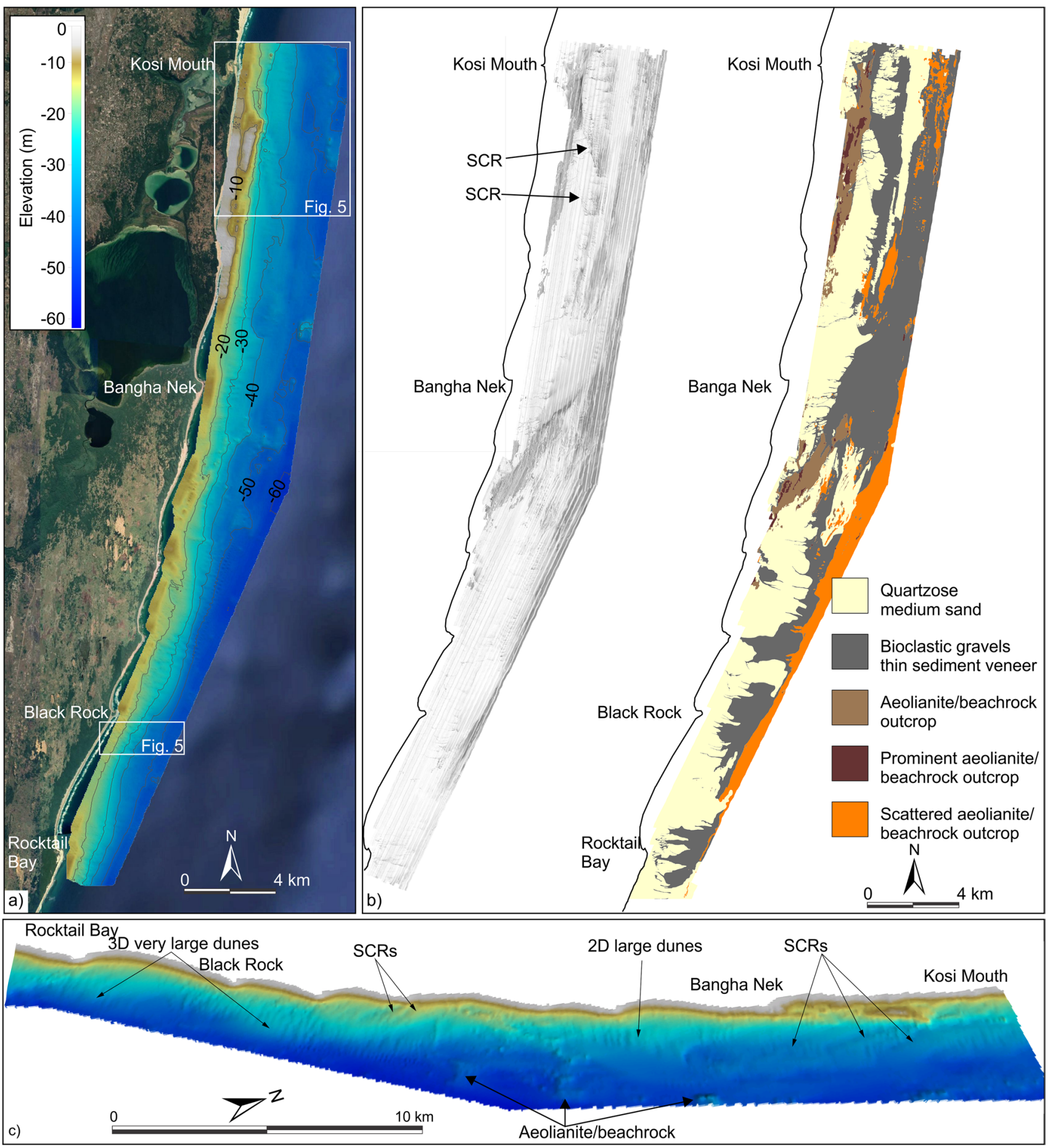

Fig. 4 a. Singlebeam bathymetry of the inner to mid shelf of northern KwaZulu-Natal. b. Accompanying side scan sonar mosaics and qualitative seafloor geology (based on Green 2009b). c. 3D perspective of the inner to mid shelf bathymetry. SCRs shoreface connected ridges

on the inner shelf of the northern part of the KwaZuluNatal shelf (offshore between Kosi mouth and Lake Nhlange) are represented by shoreface-attached ridges, oriented oblique to the coast (Fig. 4b, c). These features are superposed by very large dunes which are aligned perpendicular to the coastline. The large dunes are similar in shape (mostly 2D to increasingly 3D with increasing water depth-Fig. 5) to those dunes of the inner shelf that extend from offshore the Bangha Nek region to the south of Mabibi (Fig. 4a). The zone from Bangha Nek to Mabibi marks a change in coastal orientation from almost north-south to a NNE-SSW alignment, where the coast is 


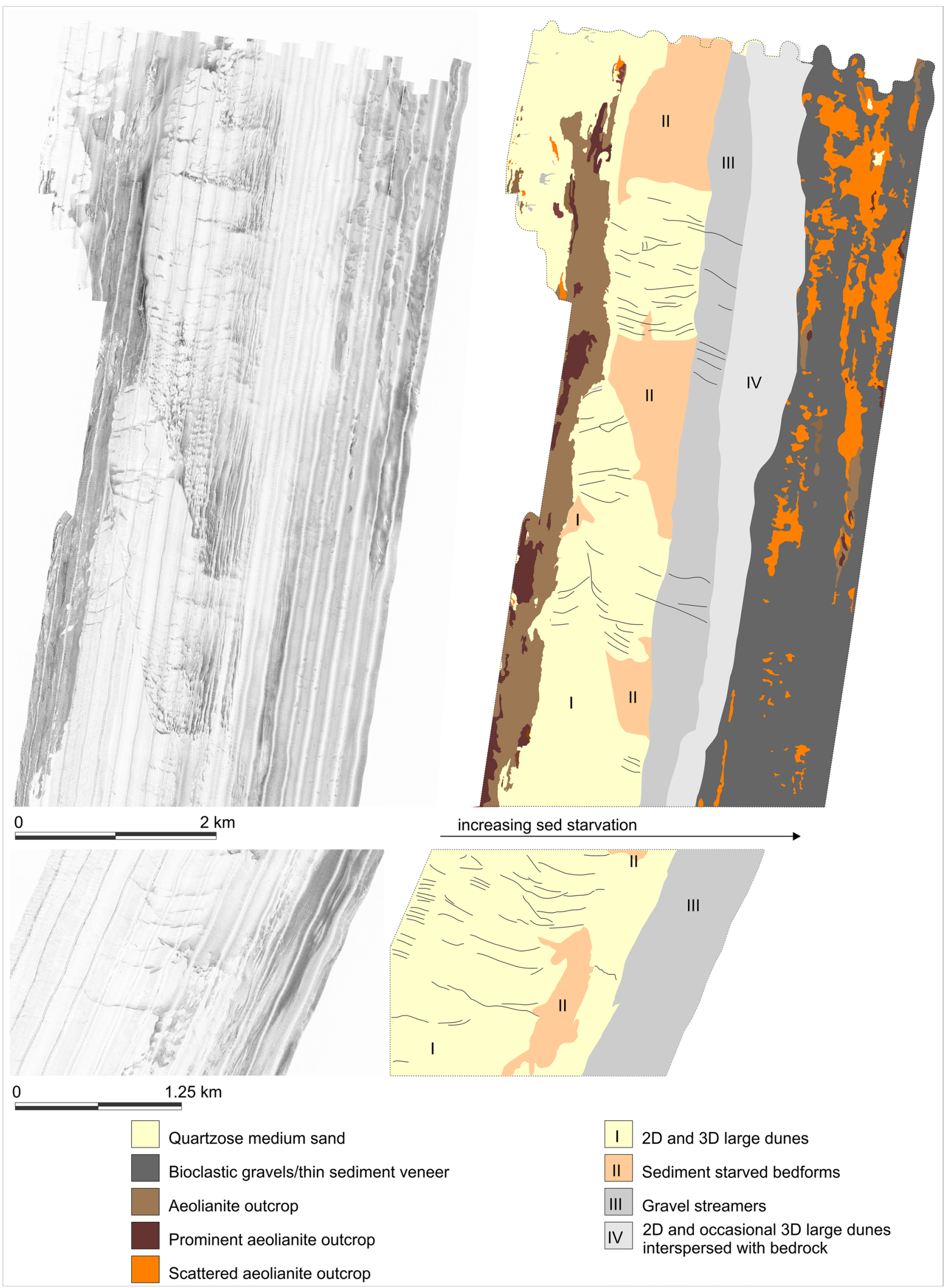


4Fig. 5 Selected side scan sonar mosaics and interpretations highlighting the major bedforms (seafloor morphotypes I-IV) and inferred seafloor textures

marked by multiple crenulated bays. Notably, the dunes located south of Bangha Nek are not superposed on larger bedforms (shoreface-connected ridges) and thus comprise the largest features on the seafloor in this area. The mostly 3D, mid-shelf dunes offshore between Bangha Nek and Rocktail Bay merge with large areas devoid of any bedforms on the outer shelf (Fig. 7). The asymmetry of these $3 \mathrm{D}$ bedforms is clear and indicates a variety of transport directions (Fig. 7). The bedforms offshore Mabibi are an amalgamation of both 2D and 3D features (Fig. 6e). These merge into the large bedform fields that occupy the midshelf (Fig. 3).

The seafloor texture and morphology of the inner to middle shelf is illustrated by the side scan sonar and sunshaded bathymetry maps of Figs. $4 \mathrm{~b}$ and 5 . These data enable classification of the shelf into four morphotypes (Fig. 5). In most of the area, the inner shelf is marked by rock outcrop (aeolianite), surrounded by sandy sediment, grading seaward into bioclastic gravels. Seafloor morphotype I (2D and 3D large dunes) dominates the areas of mostly sandy material and gives way to more sediment starved bedforms (Morphotype II) to seaward. Morphotype III (bioclastic gravel streamers) typically forms a break between morphotypes I and II and the very large dunes of Morphotype IV on the mid-shelf. These abut a seaward rocky outcrop with extensive pavements of bioclastic debris on the mid to outer shelf.

The mid to outer shelf is characterised by discontinuous dune fields of Morphotype IV (Fig. 7—marked by arrows indicating transport directions) interspersed by prominent bedrock outcrops (Fig. 6c). The dunes comprise mostly large 3D dunes, many of which display climbing or stacking morphologies. Occasional changes in shelf break orientation result in exposure of bedrock where the dunes have been diverted off shelf (Fig. 6b). In addition, some submarine canyons that impinge the shelf edge intercept and capture some of these dune fields, with dune fields absent down-drift of the canyon heads (Fig. 6d). No dune fields are evident along the outer shelf north of Mabibi, though the data coverage shifts seaward on to the upper slope in this area (Fig. 7).

Almost all bedforms encountered on the outer shelf had strongly rounded crests at the time of the survey (Fig. 8a-d). To some extent, bedform crests increase in sharpness towards the south and with distance from the shelf-indenting canyons (Fig. 8a), though the smaller climbing dunes are more peaked than the rounded, very large dunes over which they migrate. In general the continuity of the dune fields is greater in the south, and where fewer canyon heads are present.

\section{Shallow seismic stratigraphy of outer shelf dunes}

Five seismic units associated with subaqueous dunes (numbered 1-5) were identified from ultra-high-resolution PARASOUND subbottom profiles across the northern KwaZulu-Natal shelf. These are recognised by their reflection termination patterns, seismic amplitudes and internal reflection geometry. If distinguishable, sub-units are defined and termed A or B, etc. A single master reflection, SB1, underlies the unconsolidated sediments of the area, recognised by Green (2011) as the subaerial unconformity and wave ravinement combined. The interpretation of the seismic data is based on standard seismic stratigraphic principles (Veeken and van Moerkerken 2013).

\section{Unit 1: Basal package}

Where visible, the junction between acoustic basement and the unconsolidated sediments is marked by a high amplitude and irregular reflection horizon (SB1). Where sediment is thicker, this limited the penetration of the seismic tool and the surface was not evident, though observed in lower frequency boomer data outlined by Green (2011) (Fig. 3). The overlying unconsolidated sediment is variably thick and often discontinuous, with the acoustic basement/SB1 cropping out sporadically between dune fields (Figs. 9 and 10).

Unit 1 forms the basal unit of the unconsolidated sediment pile and rests atop SB1 (Figs. 9 and 10). It is discontinuous and occurs mainly in relatively thick $(\leq 15 \mathrm{~m}$ thick) sediment pockets (Fig. 9a). Unit 1 occupies isolated depressions of the acoustic basement and is characterised by occasionally undifferentiated, but more commonly relatively low to high amplitude reflections that have a subhorizontal, sub-parallel stratigraphy (Fig. 9a).

\section{Unit 2: Hummocky moderate to high amplitude reflections}

Unit 2 comprises a series of hummocky convex-up, aggrading reflections that overlie Unit 1, or SB1 (Fig. 9b). This unit occurs infrequently on the outer shelf of the study area, most notably offshore the northern part of St Lucia estuary, corresponding with a large shelf depocenter (Fig. 3d). The reflections range from moderate to high amplitude and stack vertically with $<1-\mathrm{m}$ spacing. The unit underlies gently inclined prograding reflections of the upper large dune deposits (Unit 4) and onlaps SB1 (Fig. 10a, b) if found in acoustic basement depressions where thick sediments have accumulated $(>10 \mathrm{~m})$ and where the seismic tool reveals both SB1 and Unit 2. 
Fig. 6 a Combined single and multibeam bathymetry detailing the mostly dune-free mid to outer shelf between Sodwana Bay and Leven Point. Note the inner shelf aeolianites and beachrocks. b. Very large dunes on the outer shelf, with offshelf diversion points marked by changes in shelf orientation. c. Mostly bedrock-controlled outer shelf areas. d. Large climbing 3D dune field captured by shelf impinging canyon. e. 3D perspective of large 2D inner shelf dunes transforming to $3 \mathrm{D}$ dunes on the outer shelf. Note the interception of the dunes by a large, shelf-breaching canyon head

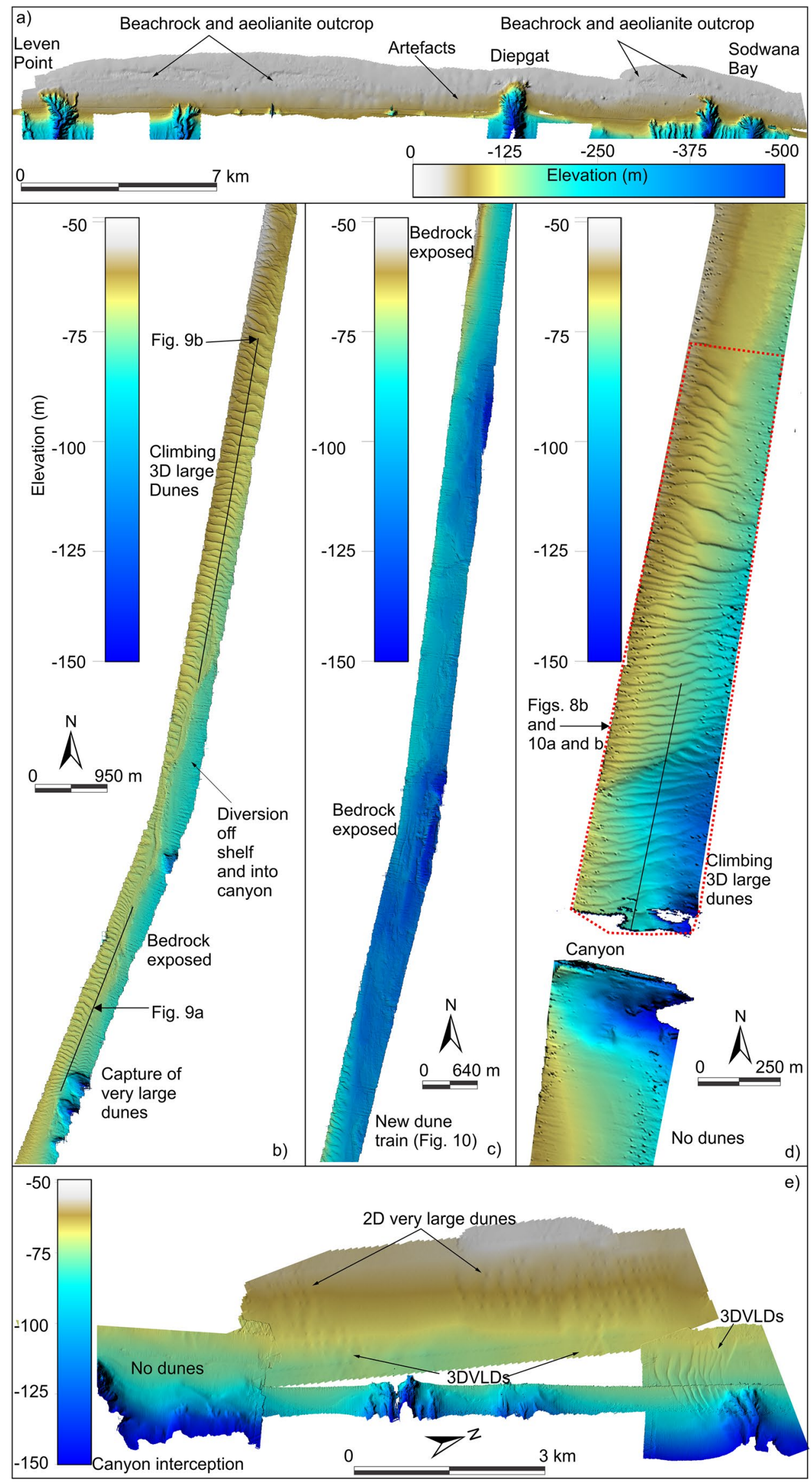




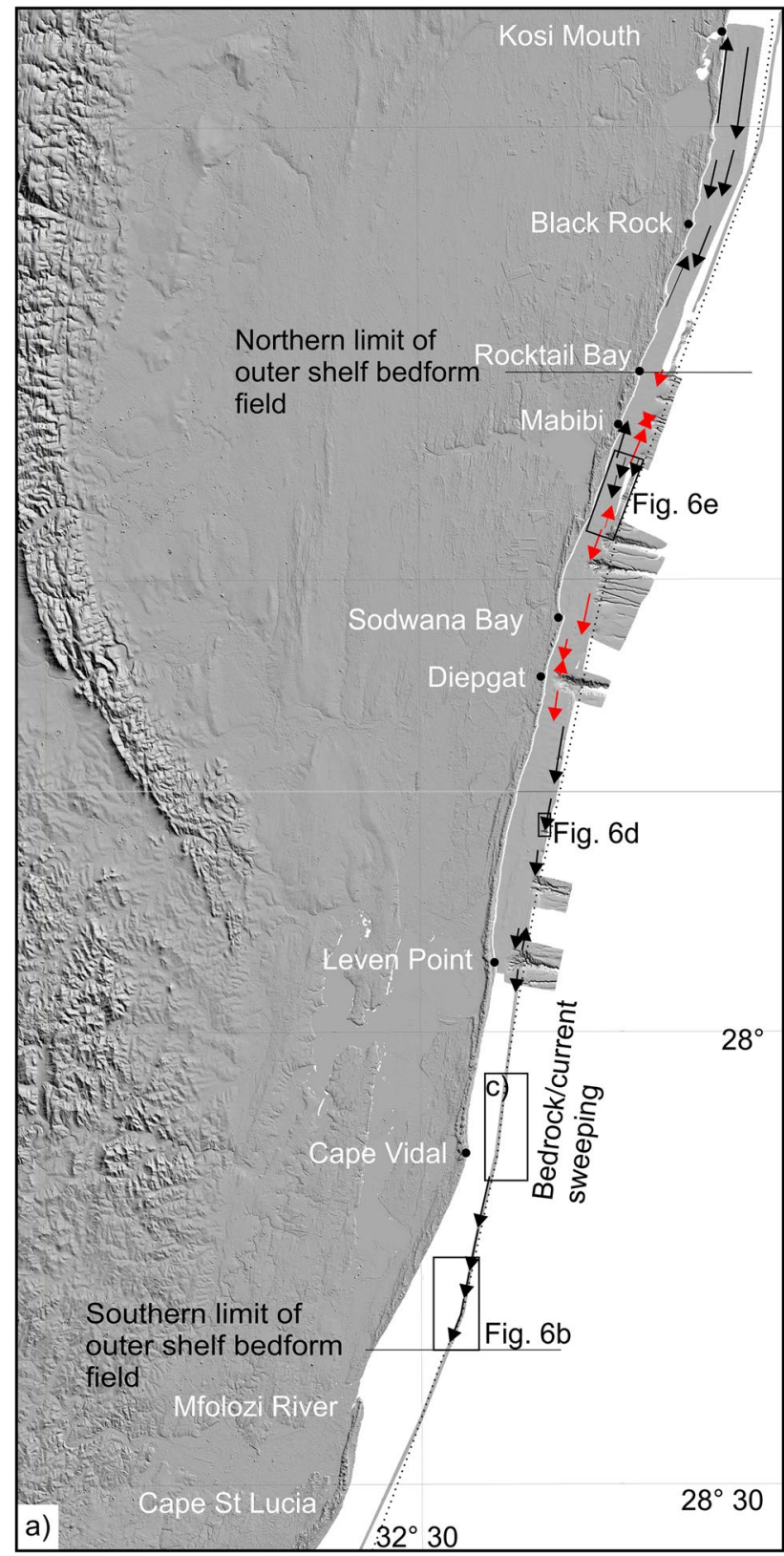

Fig. 7 Distribution of the major bedform fields of the study area. Dip orientations of the lee faces of dunes are provided by arrows (black arrows from this study, red arrows from Green 2009b). Note the bedload convergences and divergences in the inner to mid shelf, with a mostly unidirectional southerly orientation on the outer shelf

\section{Unit 3: Sigmoid prograding reflections}

Unit 3 is exclusively associated with overlying large to very large dunes of Unit 4. It downlaps Unit 2 (Fig. 10c) and is characterised by moderate to high amplitude reflections that may be parallel to oblique tangential or oblique sigmoidal. The dip angles of the prograding reflections vary from $\sim 9$ to $35^{\circ}$, dipping to the south (see Fig. 7 for lee faces dip directions).

\section{Unit 4: Upper dune packages}

Unit 4 consists of small-scale dunes that are amalgamated and/or superimposed to make up a series of larger dunes (Figs. 9 and 10). The small-scale dunes (0.1 to 2-m height) superimpose dunes with heights between $\sim 2 \mathrm{~m}$ and $10 \mathrm{~m}$. The large dunes have an internal structure that may be horizontally conformable with an upper erosional surface that truncates the inclined progradational Unit 3 (Fig. 10c). The large dunes also have internal structures characterised by high to very high amplitude reflections that are steeply inclined between $\sim 10^{\circ}$ and $40^{\circ}$ (Fig. 9). These are never steeper than the lee faces of the very large dunes that host them.

\section{Unit 5: Isolated sediment drifts}

In the absence of bedform fields, Unit 5 overlies SB1. Unit 5 is characterised by parallel and flat-lying, low to moderate amplitude reflections (if present) (Fig. 9), or it may be acoustically transparent (Fig. 10).

\section{Northern KwaZulu-Natal shelf dune morphometrics}

The morphometry of contemporary bedforms is important for the investigation of potential relationships with modern current processes, water depth and sediment supply. In this section, bedform geometry is described from inner (10-55-m water depth-mwd), and mid to outer shelf zones (80-120 mwd).

\section{Inner shelf dunes (10-55 mwd)}

Inner shelf dunes (Fig. 11) show no relationship between bedform height and water depth $\left(R^{2}=0.009\right)$. Bedform heights spread between $\sim 0.02$ (wave ripples) and $7 \mathrm{~m}$ (Fig. 11a), with the majority of the bedforms of the inner shelf ranging in height from $\sim 0.1$ to $2 \mathrm{~m}$ (Fig. 10a).

The general spacing of the bedforms on the inner shelf spans from $<1 \mathrm{~m}$ (ripples) to more than $4 \mathrm{~km}$ (shorefaceconnected ridges). Most wavelengths rest within the very large dune category ( 40-500 m) (Fig. 11b). With an $R^{2}$ value of 0.03 , there appears to be no relationship between depth and spacing. The H/L relationship of the inner shelf bedforms shows a very weak positive relationship between height and wavelength (Fig. 11c); the coefficient of determination $\left(R^{2}=0.16\right)$ indicates that only $16 \%$ of the variation is explained by the regression and that $84 \%$ depart significantly from it, probably because they were not or only weakly active at the time of the survey. 

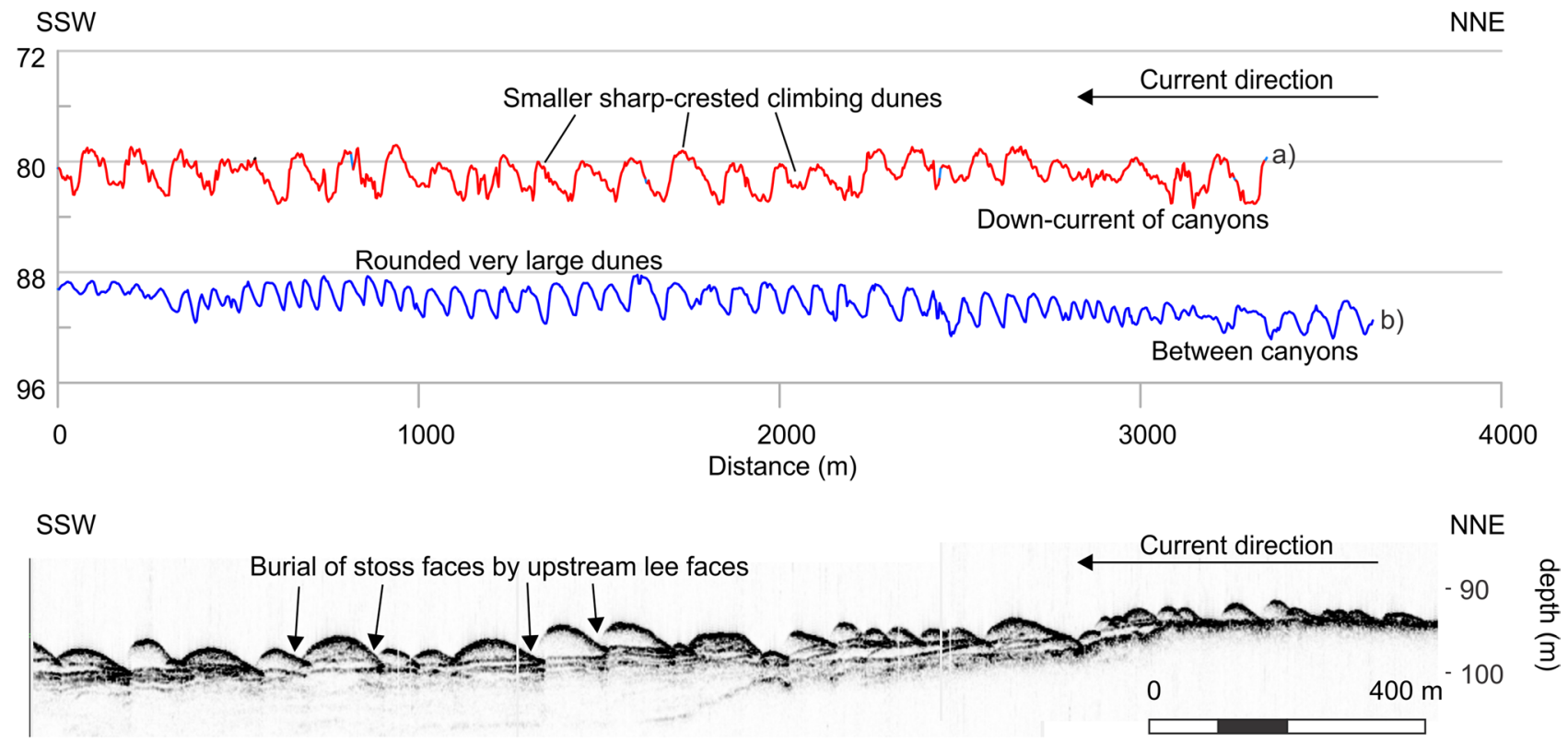

c)

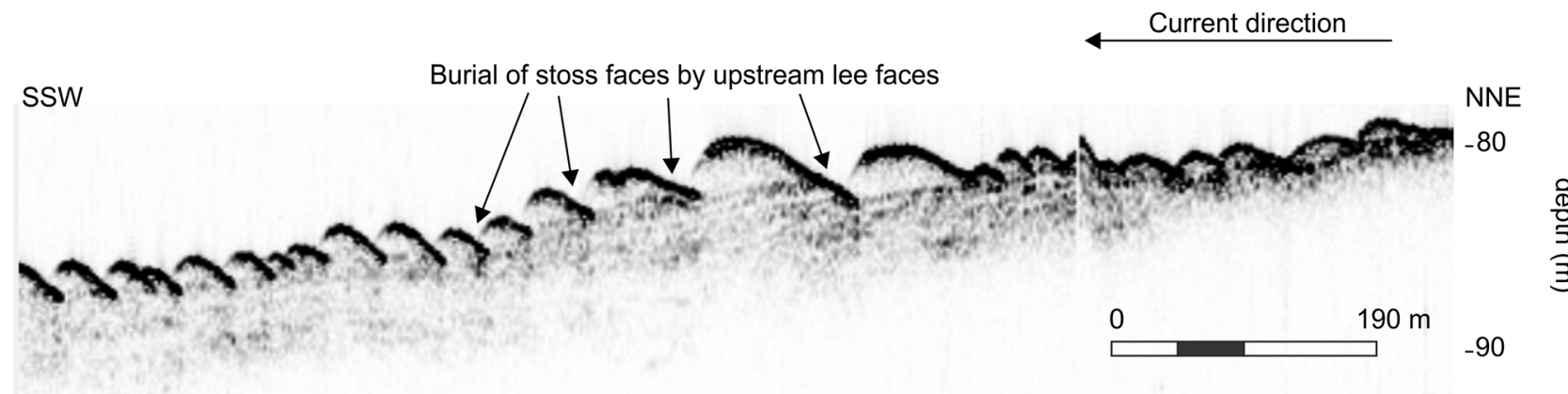

d)

Fig. 8 Bathymetric cross sections showing a very large round-crested dunes superimposed by smaller, sharp-crested large dunes (red) and $\mathbf{b}$ very large dunes with rounded crests (blue) (locations of sections on Fig. 1). The rounded crests are dominant throughout the study. Sharpcrested bedforms are found only in the southern portions of the study area, significantly down-current of any canyon features. c. Rounded

\section{Bedforms of the mid to outer shelf ( 80-120 mwd)}

In this zone, bedform height varied considerably from 0.16 to $8 \mathrm{~m}$ (Fig. 12a). With an $R^{2}$ value of only 0.006 , the scatter emphasises that the two control parameters (water depth and height) are unrelated to each other (Fig. 12a). Like the height-water depth relationships, there is no correlation between spacing and water depth $\left(R^{2}=0.0002\right)$ (Fig. 12b). Between Leven Point and Cape St. Lucia, very large dunes with the greatest crest to crest spacing are found on the outer shelf. As revealed by the coefficient of determination $\left(R^{2}=0.27\right)$, there is a weak positive relationship between the two control parameters (Fig. 12c). crests of bedforms observed in ultra-high resolution PARASOUND seismic data between Leven Point and Cape St Lucia. d. Similar round-crested bedforms observed in PARASOUND seismic reflection data mid-way Leven Point and Sodwana Bay. Note that in $\mathbf{c}$ and $\mathbf{d}$, the downstream stoss faces are buried by the upstream lee faces of successive dunes

\section{Morphometric comparisons}

For the overall data set, it is clear that bedform spacings are generally greater on the inner shelf and diminish with depth towards the mid-outer shelf (Fig. 13, yellow dots, green stars). On the other hand, bedform heights are on average lower on the inner than on the mid-outer shelf. There is an overlap between the two data sets $(\sim 40 \%)$ where the bedforms of the two regions (inner shelf vs mid-outer shelf) are observed to fall within the same height/spacing range.

When considering the H/L domains, only a small $(\sim 30 \%)$ overlap exists between the bedforms of the inner and midouter shelf which, despite having some equally large heights, have much smaller wavelengths. The observation that depth neither affects the height, nor the wavelength, of the 


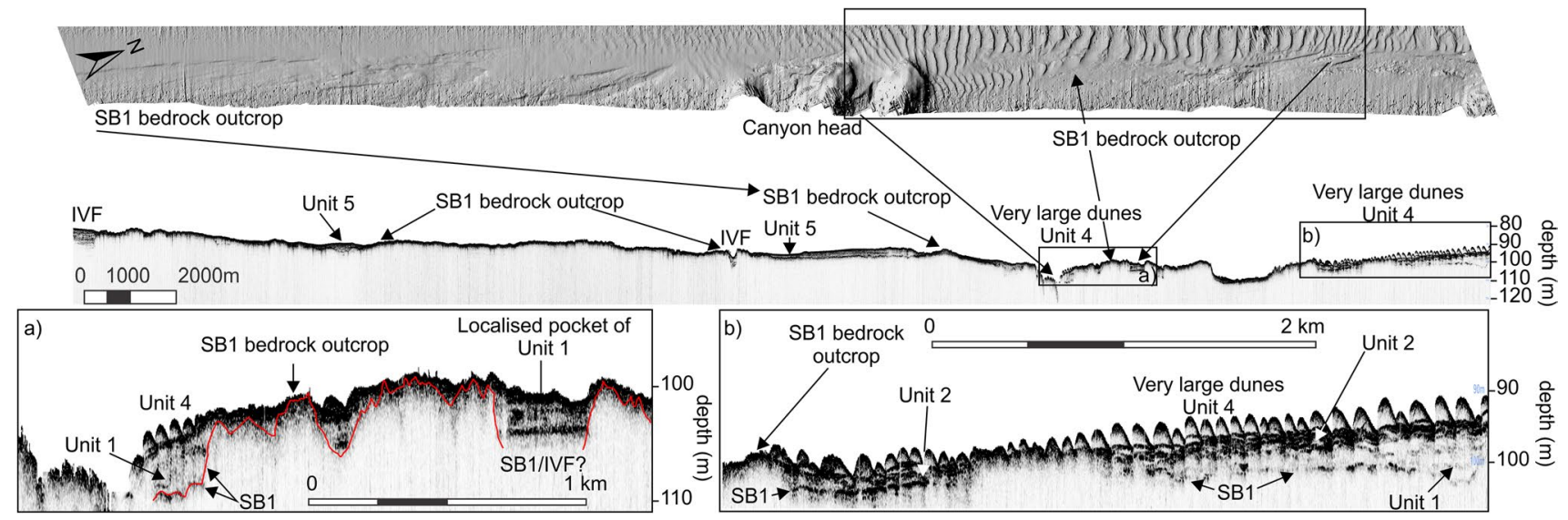

Fig. 9 Multibeam bathymetry and along strike PARASOUND seismic reflection profile detailing the seismic stratigraphy of unconsolidated sediments in which dunes have formed. Seismic data and inter- pretation illustrating detailing a the weakly developed, low amplitude reflections of Unit 1. b. Hummocky and aggradational high amplitude reflections of Unit 2. IVF incised valley fills bedforms is clearly illustrated by the non-existent correlations between the two variables from both inner and midouter shelf.

\section{Discussion}

\section{Holocene depocenters and potential for dune field formation}

Generation of large bedforms requires adequate sediment, and they are therefore associated with shelf depocenters. Birch (1996) observed substantial Holocene depocenters in the southern portions of the study area, which Shaw (1998) linked to (i) major structural offsets in the coastline, (ii) zones of bedload parting, (iii) protective headlands and embayments and (iv) areas where the current is forced offshore due to the widening shelf. Depocenters exist in the Mfolozi River mouth to Mabibi region (Martin and Flemming 1986; Green et al. 2018) (Fig. 2) and possibly at Kosi mouth. In addition, sediments discharged by rivers either accumulate in the vicinity of their mouths or are dispersed alongshore by coastal currents or offshore by near-bed hyperpycnal flows (Flemming and Martin 2018), depending on the composition and concentration of sediments (e.g. Sommerfield and Nittrouer 1999; Gao and Collins 2014).

The prominent and widely spaced bedform fields on the inner shelf can be attributed to a combination of high sediment availability and relatively weak currents. The high sediment volume is derived from either older shoreface deposits that thicken due to the steep nearshore bedrock framework (Salzmann et al. 2013), and/or newly deposited sediment from fluvial systems such as the Mfolozi River (Flemming and Martin 2018). Weak inner shelf currents are associated with return gyres in the lee of coastal offsets and cause local bedload convergences that feed the dune fields (Ramsay 1994). Conversely, the weak development of bedforms on the outer shelf reflects coarser grain sizes (Green 2009a, b) and low retention of fine-grained sediment due to the strong transporting currents.

The overall shelf sediment transport direction is to the south (Fig. 7), driven by the strong (south-westward driven) Agulhas Current, but at some places current reversals (e.g. at embayments) result in northward migrating dunes (Ramsay et al. 1996; Flemming and Kudrass 2018). Figure 7 highlights these areas, most notably along the inner shelf of areas with strong crenulated coastlines such as Rocktail Bay northward. These may indeed be strengthened during stormy periods by storm-driven flows from the south. These storm-driven flows are however too shortlived and infrequent (Corbello and Stretch 2012) to generate dunes at the scale and temporal persistence of those that occur in the area.

Flemming (2013) considers that a constant supply or local availability of sediment is needed for large dunes to develop fully. Given the low potential for sediment retention on the outer KwaZulu-Natal shelf due to the current and shelf-edge configuration where dunes are directed off shelf (Fig. 6b), the lack of sediment availability results in discontinuous bedform fields and areas of exposed bedrock, despite strong currents and coarser grain sizes that build dunes (Flemming 2000). This may be exacerbated by the interception of sediments by canyons (Fig. 6d), which results in net loss of sediments to the continental slope (Flemming 1978; Ramsay 1994).

\section{Seismic stratigraphy}

The surface that marks the transition from bedrock to unconsolidated sediments (SB1) has been linked to both the 

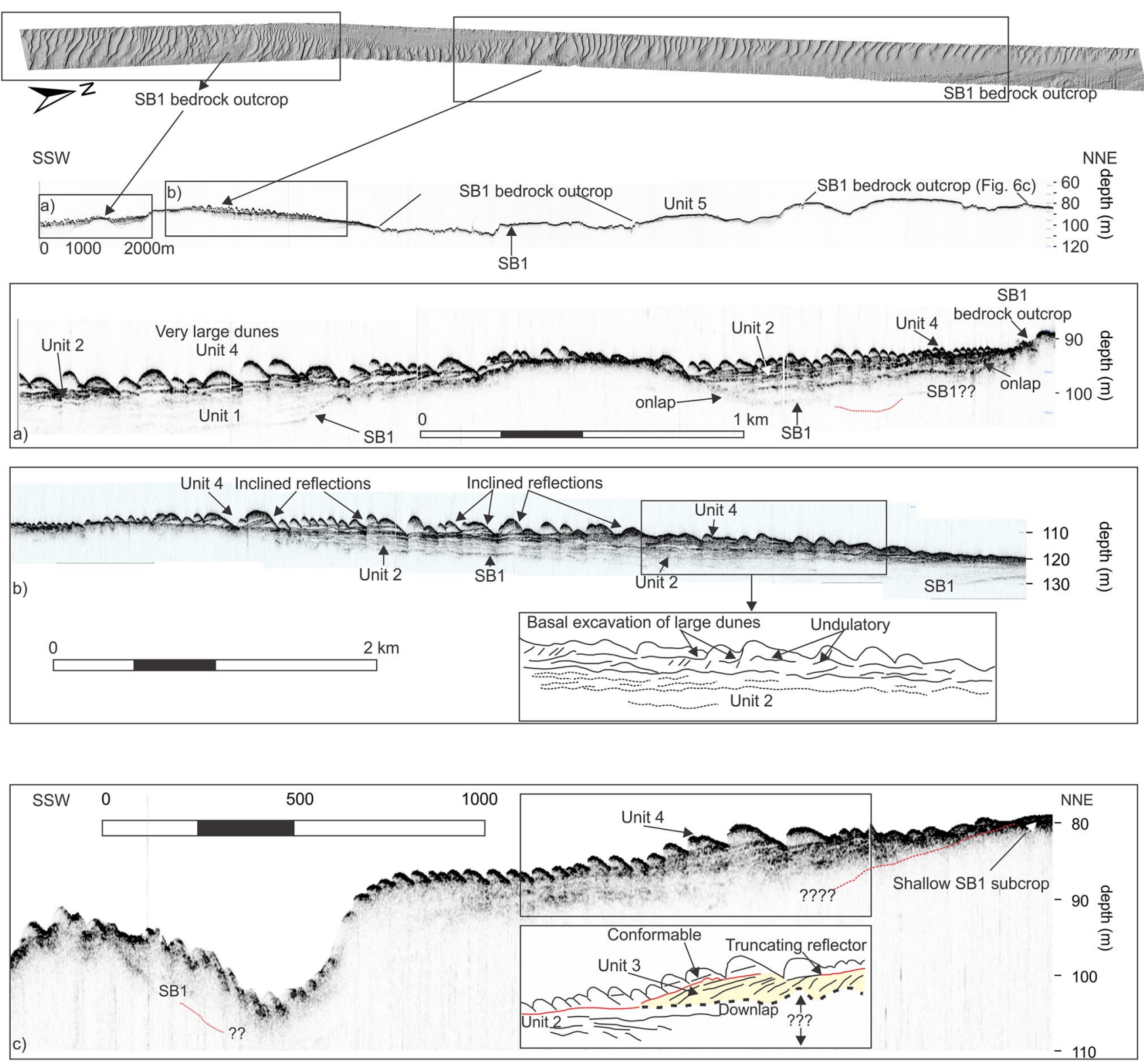

Fig. 10 Multibeam bathymetry and along strike PARASOUND seismic reflection profile. a. Seismic data and interpretation illustrating the sub-horizontal and hummocky stacking pattern of Unit 2, which forms the basal unit below the very large dunes of Unit 4. Note Unit 4's large dunes with steeply inclined internal reflections. b. Seismic data and interpretation illustrating Unit 2, overlain by Unit 4 (note the inclined reflections indicated). The enlarged interpretation details the excavation of the very large dunes of Unit 4 into an underlying set of older dunes, forming undulatory surfaces similar to Unit 2 below. c. Seismic data and interpretation showing Unit 3, with truncating upper reflection, and downlapping internal reflections with underlying Unit 2 development of the subaerial unconformity of the last glacial maximum (LGM) (Green 2009a), some of which has been reworked by transgressive ravinement (Green 2011) and later winnowing by the Agulhas Current (Flemming 1981). Superimposed on this ravinement surface is a series of five consecutive Holocene depositional units that are interpreted to have developed under progressively greater boundary current influence on the shelf.

\section{Unit 1-Aggrading basal unit (Fig. 9)}

The quasi-horizontal internal reflections of the basal unit (Unit 1) reflect an aggradational growth pattern, where appreciable quantities of sediment have accumulated, yet this unit lacks evidence of bedforms (or associated internal structure). As the lowermost unit overlying the Holocene ravinement, Unit 1 is interpreted as having formed in the early stages of the Holocene transgression when only part 
Fig. 11 Morphometric analyses of the northern KwaZulu-Natal inner shelf bedform characteristics (all fits according to power law relationship, log-log axes). a. Height vs depth with no relationship between the two. b. Spacing vs depth with no correlation. c. Height vs spacing $(\mathrm{H} / \mathrm{L}$ index $)$ showing a very weak positive correlation between the two

of the shelf was flooded and the Agulhas Current was not yet active on the shelf. Instead, these parts of the newly flooded shelf would have been dominated by wave influences. This oceanographic setting limited the potential for formation of bedforms, forming flat-lying aggrading strata instead.

\section{Unit 2-Excavated base of large dunes (Fig. 10)}

The quasi-horizontal, hummocky and aggrading nature of Unit 2 is considered to reflect reworking of sediment pockets at the shelf edge as bedforms developed on small depocentres and then migrated. The dunes observed above this unit (Unit 4) uniformly migrated south with the Agulhas Current, creating a basal erosion surface by trough scouring, simultaneously reworking their trough sediments as the dune crests prograde and grow in height. This basal 'dune' unit possibly represents previous excavation surfaces that have not been fully excavated or represent the coarser sediments that remain at the troughs (forming a coarse lag deposit), since there is not enough current strength to carry them to the dune crest. Their aggrading nature indicates abundant sediment supply at the time. This process is evident in Fig. 10b, where the large dunes of Unit 4 are seen climbing over older dunes and excavating into them, forming the hummocky and undulating surfaces that characterise Unit 2 below.

In cases where trough scouring is prevented by a hardground base, larger-generation dunes become progressively more sediment starved. As a result, the hardground becomes exposed between successive dunes, their remnant heights being too small for their spacing (Flemming 1980).

\section{Unit 3-Topographically controlled wedges (Fig. 10)}

Unit 3 exists in conjunction with Unit 2 in sedimentary pockets with larger accommodation space $(>15 \mathrm{~m})$. It is associated with breaks in topography in which it forms a prograding package dipping in a similar orientation and angle to the lee faces of the large dunes lying above. The inclined prograding, moderate to high amplitude characteristics of Unit 3, coupled with its position, resemble a deposit formed by dune field disintegration. The transition from amalgamation to splitting is associated with a velocity drop (Flemming 2000), which possibly resulted in the deposition of transported material where the topographic drop-off point occurs. As flow separates off this obstacle point, velocities decrease (e.g. Keller and Richards 1967; Morris and
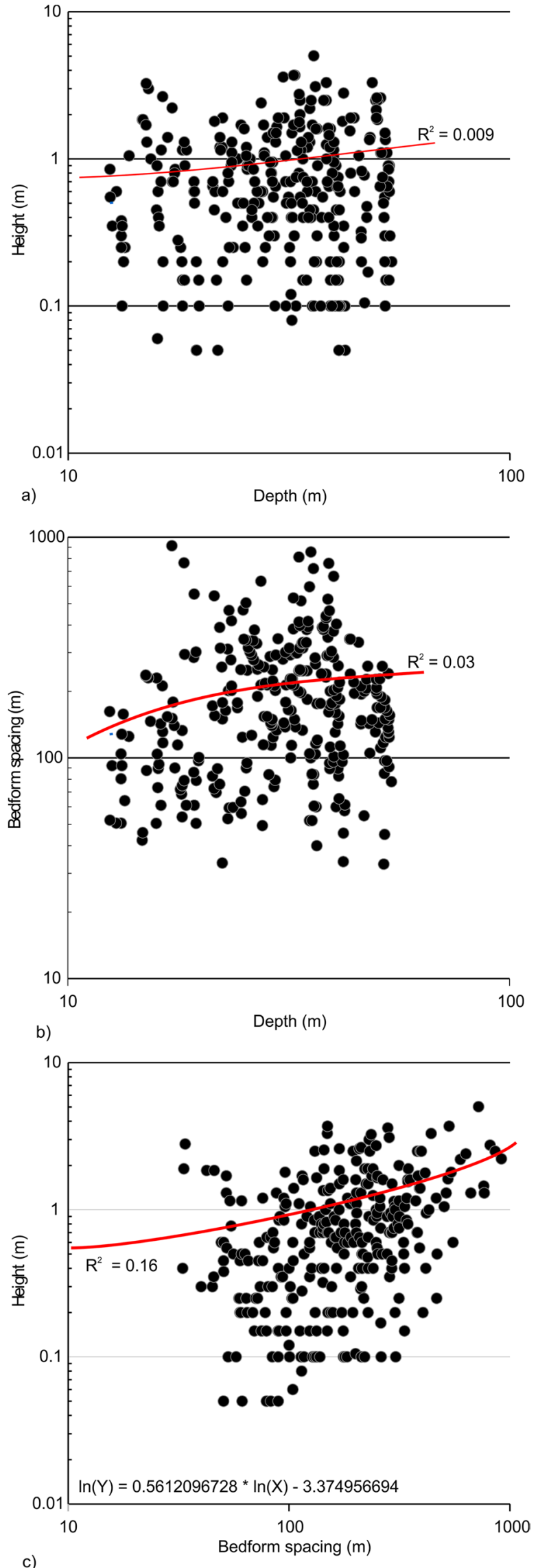
Fig. 12 Morphometric analyses of the northern KwaZulu-Natal outer shelf bedform characteristics (all fits according to power law relationship). a. Height vs depth with no relationship (linear axes). b. Spacing vs depth with no correlation between the two (linear axes). c. Height vs spacing (H/L index) showing a weakly positive correlation between the two (log-log axes)

Alexander 2003), and there is insufficient current strength to carry sediments southwards evenly throughout the pocket. Likewise, the velocity is insufficient to form dunes during this transitional flow stage. Keller and Richards (1967) show that the irregularities of the underlying bedrock surface (in this case SB1) also exert antecedent controls on bedforms by steering bottom current flows, reducing or enhancing their velocities, and producing varying sizes of bedforms relative to the sediment sizes that are available.

\section{Unit 4-Internally stratified very large dunes (Figs. 9 and 10)}

The very large dunes occur as discontinuous features throughout the outer shelf. Their discontinuity is a factor of variable sediment availability on the shelf (Dalrymple and Rhodes 1995; Wever and Jenkins 2013) and interruptions to the sediment stream by canyon heads. Despite the overall sediment scarcity, the stacking of internal reflections (interpreted as large-scale sub-horizontal aggrading beds and cross-bedding) (Fig. 10b), coupled with dunes superimposing on each other (Fig. 8), (Werner and Newton 1975), provides supporting evidence that the dune fields of the outer shelf are still growing where localised sediment supply exists.

The conceptual amalgamation processes proposed by Flemming (2000) best explain the formation of the internal structures of these bedforms, with the stacked sub-horizontal internal reflections at the base and stacked inclined cross-bedded internal reflections formed by the repetition of amalgamation and splitting processes. Berné et al. (1988) and Langhorne (1982) similarly observed sub-horizontal reflections within dunes; their cross-cutting relationship to other reflections was attributed to destruction phases during storms, a combination of wave and tidal currents truncating the crest. However, at the depth where this study is based, these basal sub-parallel reflections are probably more the result of excavation into unit 2 as the dune troughs are being reworked by the amalgamation process. The surface capping of Unit 2 is encompassed within the large dunes as sections in the trough are exposed and eroded. Sections beneath the dune crests are preserved and appear as part of the large dune.

The inclined internal cross-beds are the preserved lee slope deposits of the bedform. However, these reflections
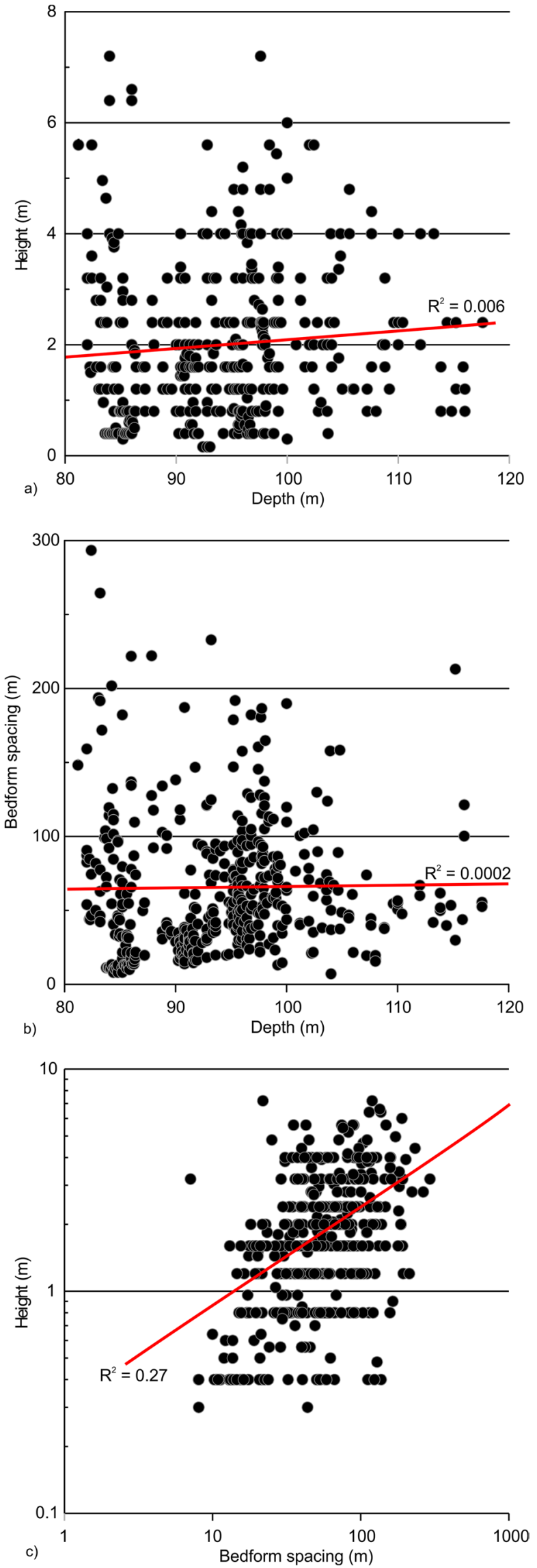
Fig. 13 The global relationship between spacing and dune height from various authors (Allen 1968; Heezen and Hollister 1971; Singh and Kumar 1974; Boothroyd and Hubbard 1974; Hine 1975; Swift et al., 1978; Flemming 1978-1981; Reinsen 1979; Rubin and McCulloch 1980; Zarillo 1982; Amos and King 1984; Fenster et al. 1990; Lanckneus and de Moor 1995; Brew 1996; Wewetzer and Duck 1999; Carling 1999; Carling et al. 2000; Lobo et al. 2000; Van Lancker and Jacobs, 2000; Wynn et al. 2002; Van Landeghem et al. 2009)

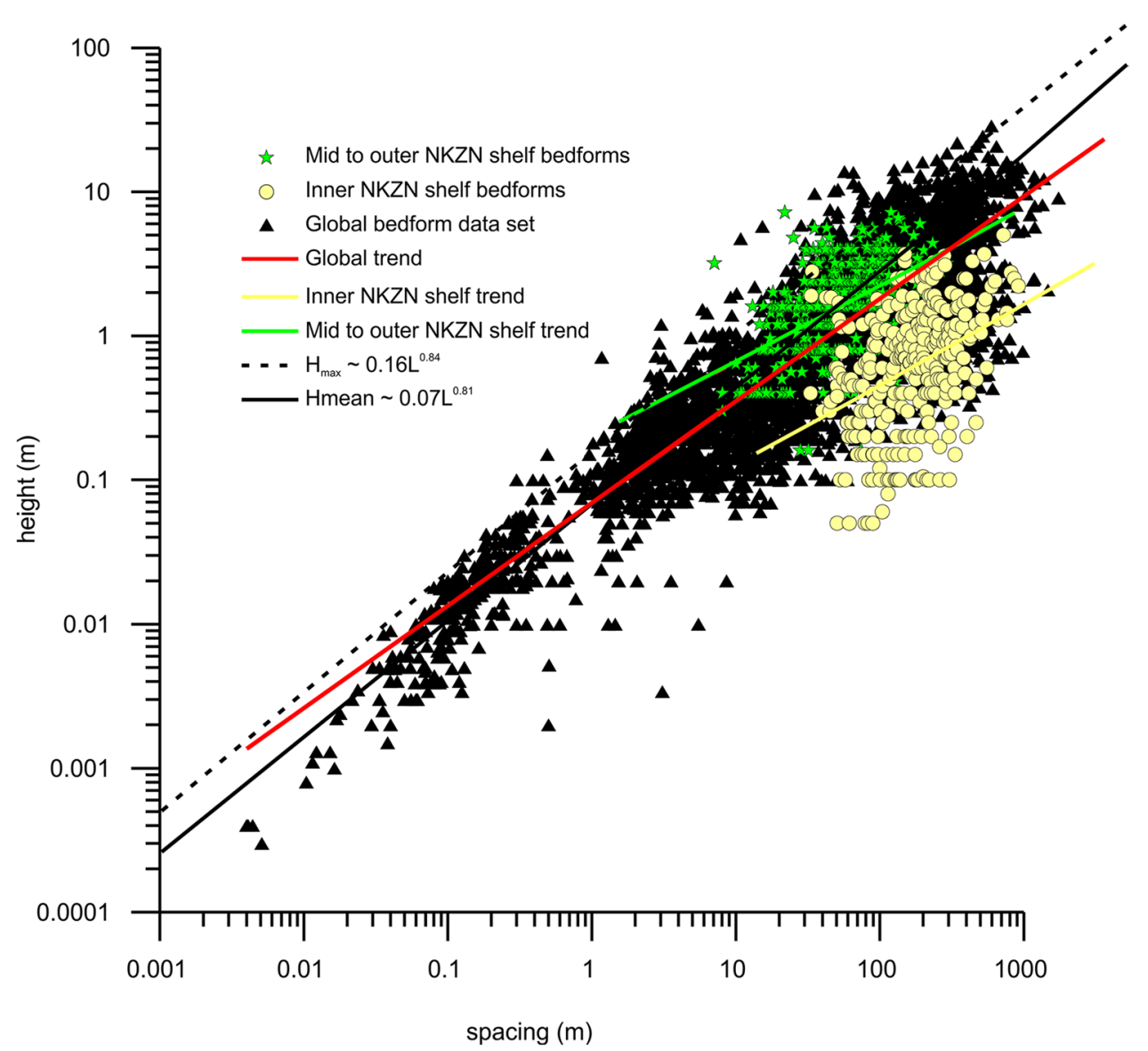

have inclination angles that are gentler than those of the present lee slopes, despite dipping in the same direction (Fig. 10). The variation in steepness may be ascribed to two things. The first may be related to the angle of section through the dune, where the seismic profile intersects the reflectors at different angles, and the dips are thus apparent as opposed to true dips. The second hypothesis is that this variation in steepness may be ascribed to a sudden reduction in flow velocity (Fig. 3d). This would lessen the crest to trough gradient and preserve the gentler internal reflections or palaeo-lee slopes as they are no longer being excavated by amalgamation processes. Given the mostly $2 \mathrm{D}$ arrangement of the dune crests and the perpendicular crossing of the crests and lee faces by the seismic profiles, we favour the latter argument.

The internal architecture reflects amalgamation of dunes, resulting from either a previously higher velocity or increased sediment supply that increased dune build-up potential (e.g. Langhorne 1982; Berné et al. 1988; Flemming 2000; Wynn and Stow 2002). A similar process was observed by Wever and Jenkins (2013) who observed that the dunes were split into segments, movement stopped and they merged with following bedforms. In the study area, these shifts between amalgamation and splitting relate to lateral shifts in the current path of a now fully current-influenced shelf. This may also produce a series of re-activation surfaces during peak and quiescent current periods, also helping to account for the discrepancy in dip angles and orientation.

The dunes appear to be asymmetrical to the south (Fig. 7) in line with the dominant flow direction of the Agulhas Current (Flemming 1978). These large dune fields on the outer shelf are disconnected from modern sediment sources (rivers Guerrero et al. 2017), so their occurrence is reliant on the mobilisation of palaeo-deposits and inner shelf sediments. Flemming and Kudrass (2018) document a large dune field from similar depths in the Mozambique Channel and link its existence to remobilised sand from within the confines of the Zambezi River's palaeo-valley and/or from a palaeodelta. Likewise, as illustrated in Fig. 2, a distinct relationship exists between older river valleys (deeper and confined areas of sediment) and large dune fields. Some of these bedforms are clearly observed in association with incised valleys of the outer shelf of the study area (Fig. 2). 


\section{Unit 5-Stratified to structureless Holocene seafloor cover (Fig. 9)}

Unit 5 comprises the loose sediment that is carried by currents without forming any specific sedimentary structures. This Holocene sediment is particularly patchy on the outer shelf, being a function of the restricted sediment supply that prevails there.

\section{Morphology and type of bedforms}

The shape, element of symmetry and scale of bedforms represent the grain size, relative strengths of the dominant and opposing currents (Agulhas Current and counter flows) and, in some cases, wave and storm (swell) modifications (e.g. Ashley et al. 1990). Both wave and current-dominated influences have been documented along the southeast African coast (Flemming 1980; Flemming and Kudrass 2018). These properties vary with the width and depth of the shelf and orientation of the coastal margins (embayments included), as this influences the degree to which the dominant current can influence the seafloor, or transport sediment out of the system and off the shelf edge. According to Flemming (1981), these processes vary from the Agulhas Current-dominated and sediment-starved outer shelf to the sediment-rich and wave-dominated inner shelf.

The various types of bedforms found on the northern KwaZulu-Natal shelf range from small ripples to sand ridges (Figs. 3 and 4). Some of the bedforms are sigmoidal, sinuous and linear shaped (Morphotype I and II), transitioning to seaward into depositional structures such as the sand ribbons of Morphotype III (e.g. Berné et al. 1988; Green 2009b; Druet et al. 2017). The bedforms transform from wave-dominated conditions (2D shape-Morphotype I) to the 3D examples of Morphotype IV with an increase in depth (inner shelf to outer shelf) and in response to increased current velocity and sediment starvation (Flemming 1978). This is likely also exacerbated by the increasingly coarse sediment towards the shelf edge that is available for dune building, a factor of the winnowing action of the Agulhas Current.

The dunes of the inner shelf vary in symmetry, especially those located in the coastal embayments (e.g. offshore Kosi Mouth and Black Rock). Variations in bedform orientation on the mid-shelf have been linked to localised bedload partings or convergences (e.g. Flemming 1978; Ramsay 1994; Ramsay et al. 1996), controlled by topographic promontories that reverse the marginal flow of the Agulhas Current by forming gyres (e.g. Schumann 1982). Green (2009b) noted several such features offshore Mabibi adjacent to the heads of submarine canyons, where bedforms migrate in a northerly direction counter to the flanking southerly migrating dunes. The inner shelf bedforms do not appear to be controlled by this mechanism, but rather portions of them are controlled by flow redirection linked to inner-shelf recirculation (Schumann 1982; Ramsay et al. 1996) and by longshore transport from south to north. This northward recirculation pattern is particularly obvious in the lee face orientations of the shoreface-connected ridges of the inner shelf (Fig. 4c and 7).

Green (2009b) showed that the dunes on the outer shelf offshore Mabibi become flatter with increasing depth, a trend apparent throughout the outer shelf populations associated with submarine canyons (Fig. 7). The rounded nature of the dunes can again be ascribed to a cessation of the Agulhas Current's influences on the outer shelf (Fig. 3). The fact that dune crests are sharper in areas not affected by canyon impingement suggests that in these areas, the degradation of the dune form is less pronounced. Dune degradation is related to either less interference by the canyons on the general flow pattern of the Agulhas Current (cf. Green 2009b), or a larger volume of sediment available for amalgamation processes as down-current sediment supply is not limited by canyon interception. The smaller, sharper peaked dunes that superimpose the very large dunes in the southern portions of the study indicate that there is sufficient sediment to build a series of active dunes that are now reworking the older degraded dunes beneath, but that the dune systems here are somewhere between the quiescent and splitting phases.

\section{Morphometrics}

Bedform spacings throughout the northern KwaZulu-Natal continental shelf vary considerably and are not correlated with the water depth in which they occur (Green 2009b). Werner and Newton (1975) concluded that dunes of the Langeland Belt (Baltic Sea) showed no correlation between spacing and water depth. The height/depth relationship similarly shows no correlation (Bartholdy et al. 2004). The occurrence of the shoreface-connected ridges offshore Kosi Mouth and the large bedforms on the inner shelf shows that the bedforms are, in this case, not restricted by water depth. This is similar to Flemming's (1978) observations, where he disputes the applicability of the empirically derived model of Allen (1968), i.e. the dependence of dune height on water depth in very shallow water, to deep water settings.

The inner and outer shelf bedforms only show a $40 \%$ similarity in their overall $\mathrm{H} / \mathrm{L}$ indices, although both have positive height/spacing (H/L) correlations (Fig. 13). The above relationship can be linked to the two-fold division of the south-eastern Africa shelf into shallow wave-dominated inner shelf and deeper current-dominated outer shelf. The overlap between the two (approximating the mid-shelf zone) is a transitional zone resulting from temporal excursions of each zone. The degree of dissimilarity in bedforms of the same shelf in close $(<5 \mathrm{~km})$ proximity shows how extreme the Agulhas Current is in fractionating bedforms. 
The most significant empirical relationship was between bedform height and spacing. The height/spacing relationship for the outer northern KwaZulu-Natal shelf lies above the global mean trend line, with a few outliers being located even above the maximum trend line (Fig. 13). H/L relationships are probably controlled by a mechanism common to all flow systems, this being clearly confirmed here by similar trends from two very different hydrodynamic settings. This may reflect spatial variability of parameters, e.g. overall sediment availability (supply, transportation and retention) and grain size.

The bedforms of the inner KwaZulu-Natal shelf plot below the global mean $\mathrm{H} / \mathrm{L}$ trend line in terms of height, however are more widely spaced when compared to the global trends (Fig. 13). This may be a factor where sufficient sediment allows larger dunes to be spaced out more liberally horizontally but does not scale in height accordingly, due to limits in the available accommodation space (water depth and storm wave base). This may also be related to reduced influence of the Agulhas Current in the shallow shelf. Periodic building of dunes may occur via amalgamation when the current core is more proximal; however, periods of quiescence predominate causing trough infilling (see below).

The bedforms of the outer KwaZulu-Natal shelf show contrasting relationships, plotting above the mean trend line (Fig. 13). This result suggests that vertical accretion has occurred in these current-swept domains due to the typically fast flow of the Agulhas Current. However, these dunes now appear to be in a state of quiescence characterised by a contemporary lowering of the dune crest. The burial of the stoss faces of the downstream dunes by the lee faces of the upstream dunes, together with the rounded nature of the dune crests and the occurrence of smaller bedforms now cannibalising the dune forms confirms this (Fig. 8). Sediment is being transported over the crests to now fill the troughs and cover the older stoss faces, reducing the wavelength to some degree and causing the crests to degrade (Fig. 3d, Flemming 2013). This is likely associated with a shorter-term meandering of the Agulhas Current core offshore, causing the flow velocities to decrease below even the splitting threshold.

Although the theoretical and empirical data of Allen (1968) suggest a dependence of bedform spacing on the depth at which the bedforms occur, this was not confirmed by the present study which found no correlation between the two variables. Likewise, the bedform heights show no correlations with depth. Similar disagreements were observed by other researchers (e.g. Jordan 1962; Stride 1970; Flemming 1978 and Wynn and Stow 2002). Flemming (1978) further noted that this deviation is always encountered in areas where the flow systems form part of a larger and deeper water body.

\section{Conclusion}

Seismic data reveal multiple depocenters on the northern KwaZulu-Natal shelf. These are relict sediment bodies associated with old fluvial courses and incised valley systems which provide key sediment sources for large, modern bedform fields, especially on the outer shelf. The outer shelf dune stratigraphy reflects initial flat-lying strata covered by sub-horizontal, hummocky and aggrading beds, overlain by inclined cross-bedded packages. The stratigraphy reflects gradual impingement of the Agulhas Current on the shelf edge during transgression, with wave-dominated influences subsequently replaced by the now contemporary influences of the onshore-offshore migration of the effects of the Agulhas Current. This reflects a landward migration of the Morphotype zones as the transgression ensued.

The dune's sub-horizontal reflections represent phases of earlier amalgamation (trough excavation) of bedforms with active dune migration, though they currently appear to be in a phase of quiescence. Shelf-edge sediment starvation, observed in areas of canyon impingement and exacerbated by off-shelf sediment transport at changes in shelf-edge orientation, is also observed. Overall, the high flow velocities of the Agulhas Current at the outer shelf can, and do, produce large bedforms via amalgamation, but only in areas not starved of sediment.

The H/L relationships are consistent with the positive trend of global measurements. The bedforms of the outer KwaZulu-Natal shelf plot above the mean global H/L trend and indicate that vertical accretion is possible in these current-swept domains, but that the dunes space closer together. These bedforms are currently degrading, based on their rounded morphologies. The lower values of the inner shelf represent limited interaction with the Agulhas Current, with general crest lowering during periods of quiescence.

Some overlap of the $\mathrm{H} / \mathrm{L}$ indices between the inner and outer KwaZulu-Natal shelf shows that both regions can form very similar bedform geometries, despite different controlling mechanisms in current and sediment supply. Equally so, significant morphological changes occur over a very short distance $(<2 \mathrm{~km})$ where the inner shelf transitions to the mid-shelf. This study highlights the differences in patterns and characteristics of bedforms, which we interpret as a response to velocity shifts in response to current meandering. It should be emphasised that studies like this are snapshots of bedform evolution in time and space, explaining in part the departures in height/wavelength relationships from the global mean.

Acknowledgements We acknowledge the captain and crew of the RV Meteor, cruise M123. Marine GeoSolutions and the Council for Geoscience (CGS) are acknowledged for the collection of the co-registered side-scan and single beam bathymetry, portions of which were included in AG's PhD thesis. In this respect, the CGS is thanked for permission 
to publish these. AG acknowledges Peter Ramsay, Andrew Richardson, Rio Leuci and Samantha Perrit for their help in the collection of the CGS datasets and their aid in the initial data processing. Older multibeam data and seismic data depicted in Figure 2 were funded by the NRF's African Coelacanth Ecosystem Programme and comprised portions of AG's PhD thesis. We especially thank the insightful and very constructive reviews of an anonymous reviewer, David Mallinson and David Mosher, who helped to improve the manuscript tremendously. We also thank the EiC, Dr. Uenzelmann-Neben for her editorial inputs.

Funding We acknowledge our funders, the Bundesministerium für Bildung und Forschung (BMBF; projects RAiN2 and MA-RAIN; Grant No. 03G0862A and 03F0731A) and the National Research Foundation (NRF).

Data availability The raw multibeam data from M123 are available on request from the corresponding author. The remaining data are proprietary and are available on request from the Council for Geoscience (side scan sonar and single beam data) and the African Coelacanth Ecosystem Programme.

Open Access This article is licensed under a Creative Commons Attribution 4.0 International License, which permits use, sharing, adaptation, distribution and reproduction in any medium or format, as long as you give appropriate credit to the original author(s) and the source, provide a link to the Creative Commons licence, and indicate if changes were made. The images or other third party material in this article are included in the article's Creative Commons licence, unless indicated otherwise in a credit line to the material. If material is not included in the article's Creative Commons licence and your intended use is not permitted by statutory regulation or exceeds the permitted use, you will need to obtain permission directly from the copyright holder. To view a copy of this licence, visit http://creativecommons.org/licenses/by/4.0/.

\section{References}

Allen JRL (1968) The nature and origin of bedform hierarchies. Sedimentology 10:161-182

Amos CL, King EL (1984) Bedforms of the Canadian eastern seaboard: a comparison with global occurrences. Mar Geol 57:167-208

Ashley GM et al (1990) Classification of large-scale subaqueous bedforms: a new look at an old problem. J Sediment Petrol 60(1):160-172

Bartholdy J, Flemming BW, Bartholomä A, Ernstsen VB (2004) On the dimensions of depth independent, simple subaqueous dunes. In: Hulscher S, Garlan T, Idier D (eds) Marine sandwave and river dynamics 2. International Workshop, Enschede, 1-2 April 2004, pp 9-16

Belderson RH, Johnson MA, Kenyon NH (1982) Bedforms. In: Stride $\mathrm{AH}$ (ed) Offshore tidal sands. Chapman and Hall, London, Chapter 3, pp 27-57

Berné S, Auffret JP, Walker P (1988) Internal structure of subtidal sandwaves revealed by high-resolution seismic reflection. Sedimentology 35:5-20

Berné S, Vagner P, Guichard F, Lericolais G, Liu ZX, Trentesaux A, Yin P, Yi HI (2002) Pleistocene forced regressions and tidal sand ridges in the East China Sea. Mar Geol 188(3):293-315

Betzer PR, Richardson PL, Zimmerman HB (1974) Bottom currents, nepheloid layers and sedimentary features under the Gulf Stream near Cape Hatteras. Mar Geol 16:21-29

Birch GF (1996) Quaternary sedimentation off the East Coast of southern Africa (Cape Padrone to Cape Vidal). Bulletin of the
Geological Survey of South Africa. Pretoria (council for Geoscience) $118: 1-55$

Boothroyd IC, Hubbard DK (1974) Bed form development and distribution pattern, Parker and Essex Estuaries, Massachusetts. Coastal Research Center, University of Massachusetts, Amherst Miscellaneous Paper 39:1-74

Brew DS (1996) Late Weichselian to early Holocene subaqueous dune formation and burial off the North Sea Northumberland coast. Mar Geol 134:203-211

Bryden HL, Beal LM, Duncan LM (2005) Structure and transport of the Agulhas Current and its temporal variability. J Oceanogr 61:479-492

Carling PA (1999) Subaqueous gravel dunes. J Sediment Res 69:534-545

Carling PA, Gölz E, Orr HG, Radecki-Pawlik A (2000) The morphodynamics of fluvial sand dunes in the River Rhine, near Mainz, Germany. Sedimentology and morphology. Sedimentology 47(1):227-252

Corbello S, Stretch DD (2012) The wave climate on the KwaZuluNatal coast of South Africa. J S Afr Inst Civ Eng 54:45-54

Dalrymple R, Rhodes R (1995) Estuarine dunes and bars. In: Perillo GME (ed) Geomorphology and sedimentology of estuaries. Developments in Sedimentology. Elsevier, Amsterdam, volume 53, pp 359-422

Dingle RV, Siesser WG, Newton AR (1983) Mesozoic and tertiary geology of Southern Africa. Balkema, Rotterdam

Dorschel B, Jensen L, Arndt JE, Brummer GJ, De Haas H, Fielies A, Franke D, Jokat W, Krocker R, Kroon D, Pätzold J (2018) The Southwest Indian Ocean Bathymetric Compilation (swIOBC). Geochem Geophys Geosyst 19:968-976

Druet M, Acosta J, Muñoz A, Barberá C, Moranta J, Jódar MJ, Martínez-Carreño N (2017) Sedimentary bedforms in the Menorca Channel Region, Balearic Islands (Western Mediterranean). In: Guillén J, Acosta J, Chiocci F, Palanques A (eds) Atlas of bedforms in the Western Mediterranean. Springer, Cham, pp $151-157$

Fenster MS, FitzGerald DM, Bohlen WF, Lewis RS, Baldwin CT (1990) Stability of giant sand waves in eastern Long Island Sound, USA. Mar Geol 91(3):207-225

Flemming BW (1978) Underwater sand dunes along the southeast African continental margin-observations and implications. Mar Geol 26:177-198

Flemming BW (1980) Sand transport and bedform patterns on the continental shelf between Durban and Port Elizabeth (south-east African continental margin). Sed Geol 26:179-205

Flemming BW (1981) Factors controlling shelf sediment dispersal along the southeast African continental margin. Mar Geol 42:259-277

Flemming BW (1988) Zur Klassifikation subaquatischer, strömungstransversaler Transportkörper. Bochumer Geologische Und Geotechnische Arbeiten 29:44-47

Flemming BW (2000) On the dimensional adjustment of subaqueous dunes in response to changing flow conditions: a conceptual process model. In: Trentesaux A et al. (eds) Marine Sandwave Dynamics, International Workshop, March 23-24 2000, University of Lille 1, France. Proceedings, pp 61-67

Flemming BW (2013) Comment on "large-scale bedforms along a tide-less outer shelf setting in the western Mediterranean" by Lo Iacono et al. (2010) in Continental Shelf Research 30:1802-1813. Continental Shelf Research 52:203-207

Flemming BW, Bartholomä A (2012) Temporal variability, migration rates, and preservation potential of subaqueous dune fields on the southeast African continental shelf. Special Publication of the International Association of Sedimentologists 44:229-247

Flemming BW, Hay ER (1988) Sediment distribution and dynamics on the Natal continental shelf. In: Schumann EH (ed) Coastal 
ocean studies off natal, South Africa. Lecture Notes on Coastal and Estuarine Studies. Springer, New York, 26, pp 47-80

Flemming BW, Kudrass H-R (2018) Large dunes on the outer shelf off the Zambezi Delta, Mozambique: evidence for the existence of a Mozambique Current. Geo-Mar Lett 38:95-106. https://doi.org/ 10.1007/s00367-017-0515-5

Flemming BW, Martin AK (2018) The Tsitsikamma coastal shelf, Agulhas Bank, South Africa: example of an isolated Holocene sediment trap. Geo-Mar Lett 38:107-117. https://doi.org/10.1007/ s00367-017-0507-5

Gao S, Collins MB (2014) Holocene sedimentary systems on continental shelves. Mar Geol 352:268-294

Green AN (2009a) Palaeo-drainage, incised valley fills and transgressive systems tract sedimentation of the northern KwaZulu-Natal continental shelf, South Africa, SW Indian Ocean. Mar Geol 263:46-63

Green AN (2009b) Sediment dynamics on the narrow, canyonincised and current-swept shelf of the northern KwaZulu-Natal continental shelf, South Africa. Geo-Mar Lett 29:201-219. https://doi.org/10.1007/s00367-009-0135-9

Green AN (2011) The late Cretaceous to Holocene sequence stratigraphy of a sheared passive upper continental margin, northern KwaZulu-Natal, South Africa. Mar Geol 289:17-28

Green AN, Uken R (2005) First observations of sea level indicators related to glacial maxima at Sodwana Bay, Northern KwaZuluNatal. S Afr J Sci 101:236-238

Green AN, Uken R, Ovechkina M (2008) Nannofossil age constraints for the northern KwaZulu-Natal shelf-edge wedge: implications for continental margin dynamics, South Africa, SW Indian Ocean. Cont Shelf Res 28:2442-2449

Green AN, Cooper JAG, Salzmann L (2018) The role of shelf morphology and antecedent setting in the preservation of palaeoshoreline (beachrock and aeolianite) sequences: the SE African shelf. Geo-Mar Lett 38:5-18

Guerrero Q, Guillén J, Durán R, Urgeles R (2017) Contemporary subaqueous dune field development over an abandoned river mouth (Ebro Delta). In: Guillén J, Acosta J, Chiocci F, Palanques A (eds) Atlas of bedforms in the Western Mediterranean. Springer, Cham, pp 37-49

Harris PT (1988) Sediments, bedforms and bedload transport pathways on the continental shelf adjacent to Torres Strait, Australia-Papua New Guinea. Cont Shelf Res 8:979-1003

Heezen BC Hollister CD (1971) The face of the deep. Oxford University Press, New York

Hine AC (1975) Bedform distribution and migration patterns on tidal deltas in the Chatham Harbor Estuary, Cape Cod, Massachusetts. In: Cronin LE (ed) Estuarine Research. Academic Press, New York, pp 235-252

Huthnance JM (1992) Extensive slope currents and the ocean-shelf boundary. Prog Oceanogr 29(2):161-196. https://doi.org/10. 1016/0079-6611(92)90023-s

Ikehara K (1988) Ocean current generated sedimentary facies in the Osumi Strait, south of Kyushu, Japan. Prog Oceanogr 21:515-524

Ikehara K (1989) The Kuroshio-generated bedform system in the Osumi Strait, southern Kyushu, Japan. In: Taira A, Masuda F (eds) Sedimentary facies in the active plate margin. Terra Science Publication, Tokyo, pp 261-273

Ikehara K, Kinoshita Y (1994) Distribution and origin of sub-aqueous dunes on the shelf of Japan. Mar Geol 120:75-87

Jones AT, Kennard JMG, Logan A, Grosjean E, Marshall J (2009) Fluid expulsion features associated with sand waves on Australia's central North West Shelf. Geo-Mar Lett 29:233-248. https://doi. org/10.1007/s00367-009-0137-7

Jordan GF (1962) Large submarine sand waves. Science 136(3519):839-848
Keller GH, Richards AF (1967) Sediments of the Malacca Strait, Southeast Asia. J Sediment Petrol 37:102-127

Komar PD (1998) Beach processes and sedimentation, 2nd ed. Upper Saddle River, NJ: Prentice Hall

Kubo Y, Soh W, Machiyama H, Tokuyama H (2004) Bedforms produced by the Kuroshio Current passing over the northern Izu Ridge. Geo-Mar Lett 24:1-7. https://doi.org/10.1007/ s00367-003-0134-1

Lanckneus J, De Moor G (1995) Bedforms on the Middelkerke Bank, southern North Sea. Special Publications of the International Association of Sedimentologists 24:33-51

Langhorne DN (1982) The stability of the top metre of the sea bed. Its importance to engineering and navigational projects. Int Hydrogr Rev 59:79-94

Langhorne DN, Malcolm J (1979) A study of mine burial in monitored hydrodynamic and sedimentological conditions, Start Bay, Devon. Institute of Oceanographic Sciences (UK), Internal Document 55

Liu Z, Berné S, Saito Y, Yu H, Trentesaux A, Uehara K, Wang X (2007) Internal architecture and mobility of tidal sand ridges in the East China Sea. Cont Shelf Res 27(13):1820-1834. https:// doi.org/10.1016/j.csr.2007.03.002

Lobo FJ, Hernndez-Molina FJ, Somoza L, Rodero J, Maldonado A, Barnolas A (2000) Patterns of bottom current flow deduced from dune asymmetries over the Gulf of Cadiz shelf (southwest Spain). Marine Geology 164(3):91-117

Lo Iacono C, Guillén J, Puig P, Ribó M, Ballesteros M, Palanques A, Farrán M, Acosta J (2010) Large-scale bedforms along a tideless outer shelf setting in the western Mediterranean. Cont Shelf Res 30:1802-1813

Lutjeharms JRE (2006) The ocean environment off south-eastern Africa: a review. S Afr J Sci 102:419-425

Lutjeharms JRE, Durgadoo JV, Schapira M, McQuaid CD (2010) First oceanographic survey of the entire continental shelf adjacent to the northern Agulhas Current: news \& views. S Afr J Sci 106:1-3

Martin AK, Flemming BW (1986) The Holocene shelf sediment wedge off the south and east coast of South Africa. In: Knight RJ, McLean JR (eds) Sands and sandstones. Canadian Society of Petroleum Geologists Memoir, 2:27-44

Martin AK, Flemming BW (1988) Physiography, structure and geological evolution of the Natal continental shelf. In: Schumann EH (ed) Coastal ocean studies off natal, South Africa. Lecture Notes Coastal Estuarine Studies, 26:11-46

McMillan IK (2003) Foraminiferally defined biostratigraphic episodes and sedimentation pattern of the Cretaceous drift succession (Early Barremian to Late Maastrichtian) in seven basins on the South African and southern Namibian continental margin. S Afr J Sci 99:537-576

Morris SA, Alexander J (2003) Changes in flow direction at a point caused by obstacles during passage of a density current. J Sediment Res 73(4):621-629

Park S-C, Han H-S, Yoo D-G (2003) Transgressive sand ridges on the mid-shelf of the southern sea of Korea (Korea Strait): formation and development in high-energy environments. Mar Geol 193(1-2):1-18. https://doi.org/10.1016/s0025-3227(02)00611-4

Ramsay PJ (1991) Sedimentology, coral reef zonation, and late Pleistocene coastline models of the Sodwana Bay continental shelf, northern Zululand. PhD dissertation, University of Natal, Durban, South Africa

Ramsay PJ (1994) Marine geology of the Sodwana Bay shelf, Southeast Africa. Mar Geol 120:225-247

Ramsay PJ, Schleyer MH, Leuci R, Muller GA, Celliers L, Harris JM, Green AN (2006) The development of an expert marine geographic information system to provide an environmental and economic decision support system for proposed tourism developments within and around the Greater St. Lucia Wetland Park world 
heritage site. National Research Foundation, Pretoria, Innovation Fund Project 24401

Ramsay PJ, Smith AM, Mason TR (1996) Geostrophic sand ridge, dune fields and associated bedforms from the Northern KwaZulu-Natal shelf, south-east Africa. Sedimentology 43:407-419

Reesink AJH, Parsons DR, Ashworth PJ, Best JL, Hardy RJ, Murphy BJ, McLelland SJ, Unsworth C (2018) The adaptation of dunes to changes in river flow. Earth Sci Rev 185:1065-1087

Reinsen, G.E. (1979). Longitudinal and transverse bedforms on a large tidal delta, Gulf of St. Lawrence, Canada. Marine Geology 31:279-296

Roberts DL, Botha GA, Maud RR, Pether J (2006) Coastal Cenozoic deposits. In: Johnson MR, Anhaeusser CR, Thomas RJ (eds) The geology of South Africa. Geological Society of South Africa, Johannesburg (Council for Geoscience, Pretoria), pp 605-628

Rubin DM, McCulloch DS (1980) Single and superimposed bedforms: a synthesis of San Francisco Bay and flume observations. Sed Geol 26:207-231

Salzmann L, Green AN (2012) Boulder emplacement on a tectonically stable, wave-dominated coastline, Mission Rocks, northern KwaZulu-Natal, South Africa. Mar Geol 323:95-106

Salzmann L, Green AN, Cooper JAG (2013) Submerged barrier shoreline sequences on a high energy, steep and narrow shelf. Mar Geol 346:366-374

Schumann EH (1982) Inshore circulation of the Agulhus Current off Natal. J Mar Res 40:43-55

Schumann EH (1988) Physical oceanography off natal. In: Schumann EH (ed) Coastal ocean studies off natal, South Africa. Lecture Notes on Coastal and Estuarine Studies 26:101-130

Shaw MJ (1998) Seismic stratigraphy of the northern KwaZulu-Natal upper continental margin. MSc thesis, University of Natal, Durban

Shepard FP (1963) Submarine geology ( ${ }^{\text {rd }}$ edition). Harper and Row, New York

Shone RW (2006) Onshore post-Karoo Mesozoic deposits. In: Johnson MR, Anhaeusser CR, Thomas RJ (eds) The geology of South Africa. Geological Society of South Africa, Johannesburg (Council for Geoscience, Pretoria), pp 541-552

Singh IB, Kumar S (1974) Mega-and giant ripples in the Ganga, Yamuna, and Son rivers, Uttar Pradesh, India. Sed Geol 12:53-66

Sommerfield CK, Nittrouer CA (1999) Modern accumulation rates and a sediment budget for the eel shelf: a flood-dominated depositional environment. Mar Geol 154:227-241

Stride AH (1970) Shape and size trends for sand waves in a depositional zone of the North Sea. Geol Mag 107:469-477
Swift DJP, Freeland GL (1978) Current lineations and sandwaves on the inner shelf, Middle Atlantic Bight of North America. J Sediment Petrol 48(4):1257-1266

Swift DJP, Freeland GL, Young RA (1979) Time and space distribution of megaripples and associated bedforms, Middle Atlantic Bight, North American Atlantic Shelf. Sedimentology 26(3):389-406. https://doi.org/10.1111/j.1365-3091.1979.tb00916.x

Van Landeghem KJJ, Uehara K, Wheeler AJ, Mitchell NC, Scourse JD (2009) Post-glacial sediment dynamics in the Irish Sea and sediment wave morphology: data-model comparisons. Cont Shelf Res 29:1723-1736

Veeken PCH, van Moerkerken B (2013) Seismic stratigraphy and depositional facies models. EAGE Academic Press, Amsterdam

Watkeys MK, Mason TR, Goodman PS (1993) The role of the geology in the development of Maputaland, South Africa. J Afr Earth Sci 16(1/2):205-221

Werner F, Newton RS (1975) The pattern of large-scale bed forms in the Langeland Belt (Baltic Sea). Mar Geol 19:29-59

Wever TF, Jenkins C (2013) Object burial by bedforms: results from instrumented modules, new data analysis concepts. In: Van Lancker V et al. (eds) MARID 2013: Fourth International Conference on Marine and River Dune Dynamics. Bruges, Belgium, 15-17 April 2013. VLIZ Special Publication 65:331-336

Wewetzer SFK, Duck RW (1999) Bedforms of the middle reaches of the Tay Estuary, Scotland. In: Smith N, Rojers J (eds) Fluvial sedimentology. International Association of Sedimentologist Special Publication 28:33-41

Wynn RB, Stow DAV (2002) Classification and characterisation of deep-water sediment waves. Mar Geol 192:7-22

Wynn RB, Masson DG, Bett BJ (2002) Hydrodynamic significance of variable ripple morphology across deep-water barchan dunes in the Faroe-Shetland Channel. Mar Geol 192:309-319. https://doi. org/10.1016/S0025-3227(02)00561-3

Zarillo GA (1982) Stability of bedforms in a tidal environment. Mar Geol 48:337-351

Publisher's note Springer Nature remains neutral with regard to jurisdictional claims in published maps and institutional affiliations. 